Historic, Archive Document

Do not assume content reflects current scientific knowledge, policies, or practices. 



\section{A Few Words Our Customers Should Read}

ORDERS SHOULD BE GIVEN EARLY. Many persons will wait until they are all ready to set plants or trees and then send in their orders, expecting that we can fill them immediately. When we receive an order we immediately deduct the number of trees called for in each variety from our supply of stock in these varieties in the nursery and we consider them sold and late orders have to take what is left. By having orders in carly we can give them better attention, plan the packing and shipping to better advantage, and with less liability of any mistakes being made. Write your name, post office and state distinctly, and be sure that you do this every time you write. If purchasers choosc, they can leave selection with us, merely stating the proportion of summer, fall and winter, or early medium or late fruit wanted, as our experience enables us to select such sorts as are adapted to the locality.

ERRORS. Immediate notice should be given us of any error in filling out an order, so that we may rectify the mistake, or give a satisfactory explanation, which is cheerfully done in all cascs. We disclaim liability for losses arising from defective planting or subsequent cultivation and treatment. A continuation by the purchaser of the careful handling and earnest effort given the stock up to the time of its leaving our hands will ordinarily leave no room for losses or complaints.

GUARANTEE. While we exercisc the greatest care to have all trees, shrubs and plants true to name and healthy, and hold ourselves prepared to replace, on proper proof, all that may prove otherwisc, we do not give any warranty, express or implied, and in case of an error on our part it is mutually understood and agreed between the purchaser and ourselves that we shall not, at any time, be held responsible for a greater amount than the original price of the goods.

CARE OF TREES AND PLANTS ON ARRIVAL. If not ready to plant the stock the day it arrives, or if you have more than you can plant within a few hours, it should be at once heeled-in. Selcet a well-draincd spot, dig a trench about 18 inches deep, sloping on one side, and place the roots in the bottom of the trench, with tops leaning up the sloping side. Spread out the trces so that the earth will coms in contact with crery root, sift fine dirt in among the roots, fill the trench partly full, and press firmly with the feet. Fill up lerel with the top of the ground and press again with the fect, covering with loose dirt. Trees thus "hceled-in" "will keep in good condition a long time. Do not cover with litter or straw, as it will harbor micc during winter.

IF STOCK IS FROZEN WHEN RECEIVED, bury the package, unopened, in well-drained ground, or place in a cool cellar, so that it will thaw out slowly and gradually without being exposed to the air.

IF STOCK SHOULD APPEAR DRY OR SHRIVELED when rccived, through delay in transit or any other cause, take from the package and plunge into water, or bury in the ground in an inclined position so as to cover with the carth; thoroughly soak with water and let remain for twenty-four hours or more until a fresh, plump appearance is regained, when the stock may be planted.

PLANTING. If trees fail to succecd when planted, it is considcred always in order tc abuse the nurseryman. But rcmember this, if you plant carelessly you will be the loser: nothing can prevent it, not even abusing the nurscryman. Plow and pulverize the soil thoroughly. Lay off in rows, north and south, as wide as you wish, and opeil the rows with the plow as dceply as possible. It saves half the digging. Dig the holcs wide enough to admit the roots i: their natural position, without cramping, and decp cnough to allow the trces to stand an inch deeper than they stood in the nurscry. Dwarf pears should be set deep enough to cover the quince stock on which they arc worked. Throw the surface and subsoil into separate piles. Cut off smoothly from the under side all broken or bruised roots, and cut back the last scason's growth of top one-half to two-thirds, leaving two or three good buds to cach branch, except for fall planting in cold climates, when it is best to defer top-pruning until spring, just before the buds start. At all times keep the roots carefully protected from the sun and wind. Place the tree in the hole; fill in with fine surface soil, for corering the roots, and this should te carcfully worked among them. If the ground is dry, it is well to pour in some water when the hole is partially filled. See that the ground is firmly and solidly' packed weer all parts of the roots, so that there will be no opportunity for dry air or frost to enter and destroy roots deprived of the full benefit of their natural protection. Omission to pack the carth solidly is the most frequent cause of failure in planting nursery stock. Fill the holes full enough to be cren with the surrounding surface after the fresh earth settles. Always remore the labels when planting. If these are lcft until the trees arc grown, the connecting wire often cuts into and destroys the tree or branch to which it is attached. 


\section{IMPORTANT POINTS FOR PLANTERS}

NEVER PUT ANY MANURE IN THE HOLES. A little bone-dust or good rich soil is best in the bottom of the hole. Fertilizers should be applied to the surface and worked in. A covering of coarse manure, straw, litter, hay, or even stones, given the first season, will retain the moisture and prevent injury from drought.

SMALL FRUIT PLANTS should be set in a pail containing two or three inches of water and taken out one at a time as planted, not allowing the roots to be exposed to the sun or air. If not ready to plant strawberries on arrival, do not pour water on them in the package or in the bunches, as they will surely heat and spoil. They may be spread out thinly in shallow trenches, with their crowns even with the surface, heeled-in, as advised for trees, sprinkled with water and shaded for a few days.

CULTIVATE your valuable young trees and shrubs, at least as well as you do your cabbage or corn, till July 1st, then sow a cover crop of crimson clover, cow peas, or oats for winter protection. Whoever puts grass in a young orchard does one of the things most certain to cause failure.

\section{NUMBER OF TREES ON AN ACRE AT A GIVEN DISTANCE APART}

3 feet apart each way......... 4, 4,840

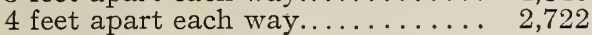

6 feet apart each way........... 1,210

8 feet apart each way............ 680
16 feet apart each way........... 170

20 feet apart each way............ 108 $16 \times 20$ feet apart each way......... 136 $20 \times 30$ feet apart each way......... 72

\section{SUITABLE DISTANCES OF TREES, ETC., IN PLANTING}

Apples........30 to 40 feet apart each way Pears, strd...20 to 25 feet apart each way Pears, dwarf.. 10 to 12 feet apart each way Cherries......18 to 20 feet apart each way Plums.......16 to 18 feet apart each way Peaches......16 to 18 feet apart each way Quinces.......10 to 12 feet apart each way
Currants.....3 to 4 feet apart each way Gooseberries..3 to 4 feet apart each way Raspberries...3 to 4 feet apart each way Blackberries..4 to 6 feet apart each way Strawberries.. $1 \frac{1}{2}$ to 3 feet apart each way Grapes.....8 to 10 feet apart each way

In finding the number of plants or trees that a piece of ground will hold, determine the distance you are to set them apart; pace your piece of ground to find how many rows you will have; also find how many it will take for each row; find the product of the two and you will have the number that you want.

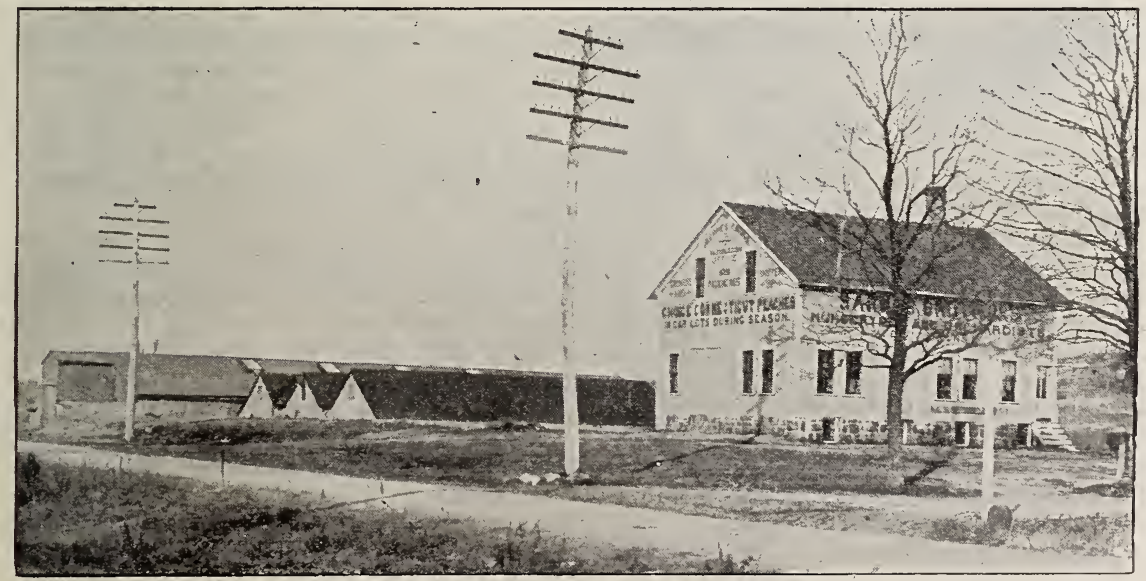

View of our Office, Packing and Storage Buildings.

Colony Street, the macadamized street passing our buildings was formerly known as the "Old Colony Road" between New Haven and Hartford, used by the first settlers of the state. 


\section{IN T R O D U C T O R Y}

It gives us great pleasure to greet our friends and customers, and we wish to thank those who have so kindly and liberally patronized us in the past. The many acknowledgements by letter of entire satisfaction with stock received by customers the past season were quite gratifying.

It is not our ambition to do an immense wholesale nursery business but rather to carry on a carefully conducted retail trade, making sure that every customer is well served and given full value for his money.

Keeping in mind that for the amateur as well as the large commercial growers a few of the best tested varieties are better than a large assortment of doubtful ones, we have discarded from our lists and discontinued growing many varieties we have found to be worthless or undesirable. Our list may not be as long as some but our aim has been to grow and offer only varieties of real merit. These include the old varieties that have proven themselves worthy and new varieties that promise to prove productive and profitable for the planter.

We have as nice a lot of Peach and Apple trees as were ever grown in a nursery; straight, clean, handsome trees, well rooted and all right in every way. We have made a specialty for years of growing these trees and it has become a science with us and a matter of pride to produce the best that can be grown. We dig our trees with a machine digger which gets practically all the valuable root system, a great advantage, leaving the trees in much better shape for successful planting than by the old way of digging trees by hand. We spend much time and care in grading our stock, making several different and distinct grades to meet and suit the varying demands of our customers.

We have two large fumigating houses and fumigate all stock sent out with Hydrocyanic acid gas, as an effective safeguard. Entomologist's certificate of inspection accompanies shipments.

We employ skilled and experienced help in digging, handling and packing our stock, giving it constant personal supervision, and every known precaution is taken to have all stock true to label and handled and packed in such a way as to reach the customer in the best condition.

We think we have superior advantages over many of our competitors who solicit trade. It is not common that nurserymen have and control, personally, in conjunction with their nursery work, large orchards of bearing trees. We have been doing this for some years and are pleased to say that when we speak of our trees being true to name we mean just that.

Our entire time from boyhood has been given to growing fruits, trees and plants. Having only limited capital and little experience we started in a small way, feeling our way along and trying each year to increase our business. We have given close personal attention to our business, aided by competent and experienced foremen, and now we have over 1,000 acres in this state used in our business and having thereon peach orchards containing sixty to seventy thousand trees and of apples about five thousand trees, the remainder being devoted to small fruits, nursery stock and general farm operations.

We are on the main line of the N. Y., N. H. \& H. R. R., about twenty miles from Hartford, fifteen miles from New Haven and three miles from Meriden, and are also connected by trolley with these cities. We have a long side-track next to our packing house which we use to great advantage in shipping. We are equipped to handle and do much of our packing under cover and if the planter does his part faithfully when he receives his order, success with our stock is certainly assured.

We are glad to have our friends and customers come and inspect our plant and our stock, and see how and where we conduct our business. Visitors are welcome and where practicable we think it often more satisfactory to those who buy extensively to come in person and see us. But customers wishing to buy of us should not wait till the busy packing season when our time is too much taken up to give them the attention we would be glad to. It is far better to engage early what is wanted, before our lists of varieties are broken up and depleted. You can call us up by telephone from any point in Connecticut, for 25 cents or less, and from long distance points at reasonable rates. Correspondence solicited. Letters, lists for estimates and inquiries concerning anything in our line will be promptly and carefully attended to.

To fully satisfy every customer that his interests are carefully considered when he entrusts his orders here, is our earnest ambition. 


\section{P E A C H E S}

\section{A Few Hints on the Successful Growing of the Peach}

The growing of Peach Trees is our specialty. We fully believe that our combination of soil and methods of handling taken together produce a tree of the very best character, either for the orchard man to plant or for the purposes of the fruit garden. That our trees "prove out" satisfactorily we are bound to believe from the character of our orders from those who best know how to plant.

Our trees are grown from the best obtainable seed. We renew our buds every two or three years by getting our buds from bearing trees in a section free from "yellows" and bud in a portion of our nursery; the next year buds are taken from trees grown from these buds to bud the nursery thus insuring healthfulness. Nobody is permitted to cut buds for propagating except a thoroughly competent man interested in sustaining the good reputation of our Company. You will often see concerns advertising peach trees grown from their own bearing trees. We would caution customers to avoid buying such trees, for there is great danger in trees so propagated of the dreaded "Yellows" and "Little Peach." These diseases are quite likely to be transferred or inherited when buds are taken from bearing orchards in the "Yellows Belt," which now includes nearly all the peach growing districts of the eastern and northern United States.

\section{HINTS ON SOIL AND CARE} OF TREES. Peaches can be grown on a great variety of soils with varying success; but in selecting an orchard site we prefer one that has lain idle for years with soil both dry and strong. If the soil is not fertile to start with, it can be enriched as the trees grow. Land that will produce fifty bushels of corn per acre would, with thorough cultivation, bring a Peach orchard to a bearing age in vigorous condition. Worn-out land can be made profitable Peach land, if a liberal use is made of wood ashes, or a mixture of ground animal bone and muriate of potash. Land of intermediate fertility should be treated as the condition requires, using more or less fertilizer as may be needed to induce a moderate wood growth.

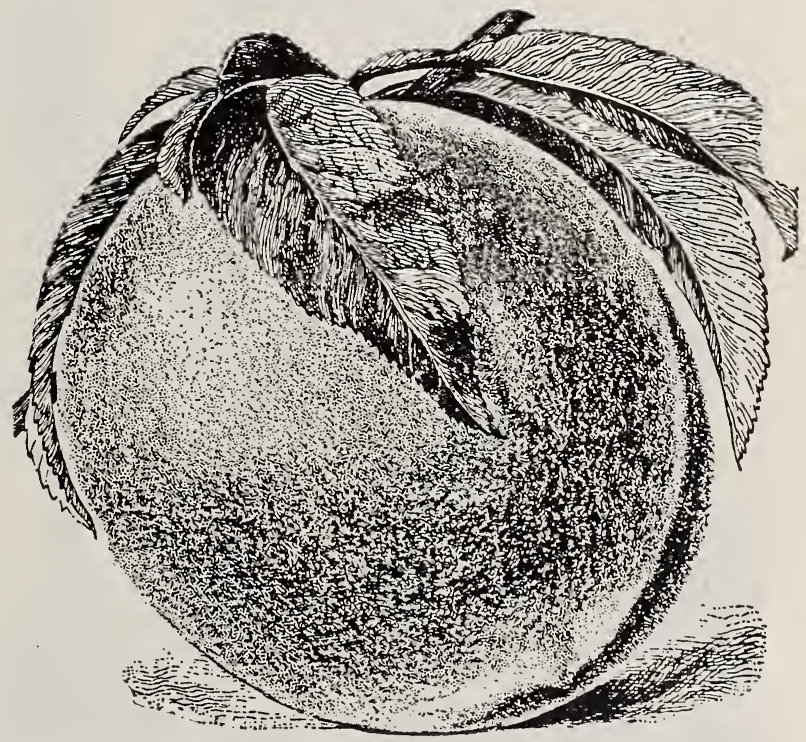

GREENSBORO PEACH

DISTANCE OF PLANTING must be governed by local conditions. On rich, heavy soil, trees should be planted 18 feet apart; on average land, 16 by 18 feet is about right, while on light land 16 by 16 feet will not be too close. A few orchard men are planting 10 by 18 and 10 by 20 and after getting one or two crops cutting out every other 10 foot tree, this leaving the maturing trees ample space to develop in as well as doubling the yield of first crops.

IT IS IMPORTANT that the young trees should be properly pruned at the time of planting. All side branches should be cut back to within a half-inch of the main stem, this stem itself being cut back at about two thirds the distance from the ground. Small trees should be pruned to a whip, cutting back the stem very nearly one-half the way to the ground. Afterward all sprouts should be removed except just what are wanted for the new top of the tree. After this it will be necessary to prevent the tops getting too dense, as a result from using too much manure or too severe pruning, by thinning out part of the new growth.

THOROUGH CULTIVATION is of much more importance than fertilization, and is indispensable to success. After an orchard has reached bearing age its condition must be an index to after treatment. A moderate growth only is required. An excessive growth of wood and foliage should be avoided, and this can usually be regulated by withholding fertilizer and cultivation. The beginner will soon discover that on rich land trees with 
excessively dense foliage will not produce brilliant colored fruit of fine flavor; but on poor land some of this luxuriant growth will be desirable and can be induced by liberal broadcast application of fertilizer. Phosphoric acid, potash and clover are best for light or sandy land, which is usually deficient in potash. We have found wood ashies to be a most complete fertilizer for Peach trees, but if some nitrogen is needed to induce more wood growth, a good grade of bone or tankage is always in order to use, giving both nitrogen and phosphoric acid. Avoid the use of dissolved rock in combination with wood ashes, but otherwise its use gives a cheap source of phosphoric acid and with muriate of potash gives a very low priced fertilizer.

BORERS. The best method of caring for the korers is as follows: Mound up with

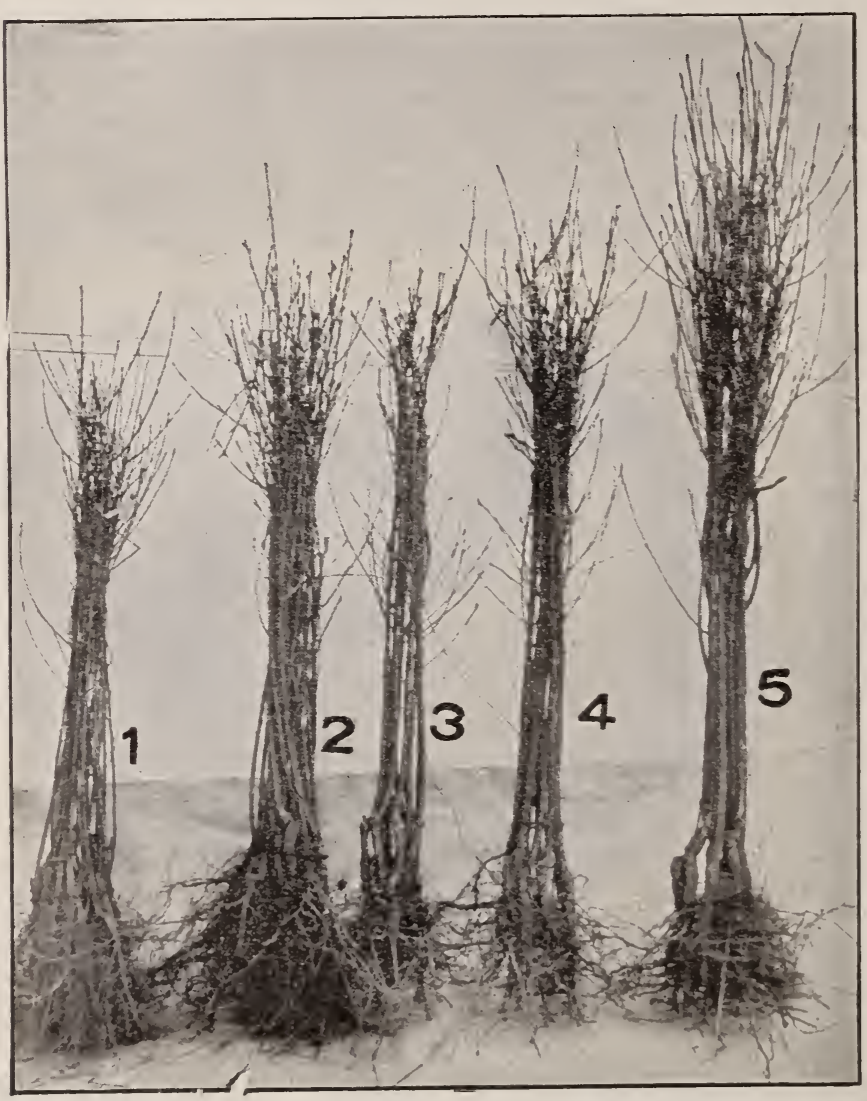

This photograph illustrates the way we grade and bunch our Peach trees. Beginning at the left, Fig. 1 shows our 2 to $3 \mathrm{ft}$. grade tied in bunch of 25 . Fig. 2 our 3 to $4 \mathrm{ft}$., light, calipering just under 7-16th inch, tied in bunch of 25 . Fig. 3 , our 3 to $4 \mathrm{ft}$. regular grade, calipering $7-16$ to $1 / 2 \mathrm{inch}$, tied in bunch of ten. Fig. 4 , our $1 / 2$ to 9-16 inch grade in bunch of ten. Fig. 5, our 9-16 inch and up grade in bunch of ten. Our two grades of 3 to $4 \mathrm{ft}$. trees are fully as good as the "seconds" of other firms. Notice how evenly each grade runs. We grade our trees almost entirely by caliper instead of height.

We wish to particularly emphasize this one point: Get good stock whatever it costs. It is cheaper in the end than any amount of trash given you.

Twenty-five years ago the great cry was "you will overdo the business." This same prediction has been made many times since, but largely by people who neglected to plant or those who after planting failed to care for their orchards intelligently.

It is not too much to expect a peach orchard to have paid for itself at five years of age. An investment yielding ten per cent. dividends and safe is considered a gilt edge proposition. An investment in a peach orchard, according to now well-known conditions, is a prososition many times hetter than ten per cent. stock. 


\section{GENERAL LIST OF PEACHES}

Arranged as nearly as possible in order of ripening. Differences in seasons, soil, location, culture, and age of trees all have their influence on the time of ripening of the different varieties.

GREENSBORO. A hardy, early, peach ripening the latter part of July. It is beautiful in appearance, a large white peach, one side covered with light and dark crimson, and freestone when fully ripe. The fruit sold readily the past summer for $\$ 1.25$ per basket at wholesale. We regard this variety as a valuable market variety to start the season with.

"Its large size, attractive appearance, and reliability in bearing combine to make it one of the best of its season."-Ohio Ex. Sta. Bull. 170.

"Largest of all early peaches, beautifully colored with light and dark red, shaded with yellow, which makes it a great beauty."-J. Van Lindley Nursery Co.

WADDELL. Fruit medium to large, oblong; color, creamy white, with bright blush on sunny side, often covering two-thirds of the peach; freestone and a good bearer and shipper, ripening two weeks before Mt. Rose.

"An excellent medium early variety for home and market, stands shipping well, even long distances."-Ohio Ex. Station.

CARMAN. This variety is almost as large as Elberta, of nearly same shape; white with beautiful red cheek, one of the most hardy and reliable bearers, and the market has never yet -been fully supplied with fruit of this variety and we recommend it for commercial planting. One week before Mountain Rose.

"Quality extra good, well worth planting."-H. E. Van Deman.

"In many respects the most profitable and valuable peach in America." - J. H. Hale.

HIELEY. This seedling of Belle of Georgia, one of the best of all peaches of North China type, the kind that are among our most hardy, is white nearly covered in red, is of good size and quality, and a perfect freestone. We recommend it for commercial planting; ripens just before Mountain Rose.

"Take my word for it, don't miss planting Hieley, it is a money maker, sure."-J. H. Hale.

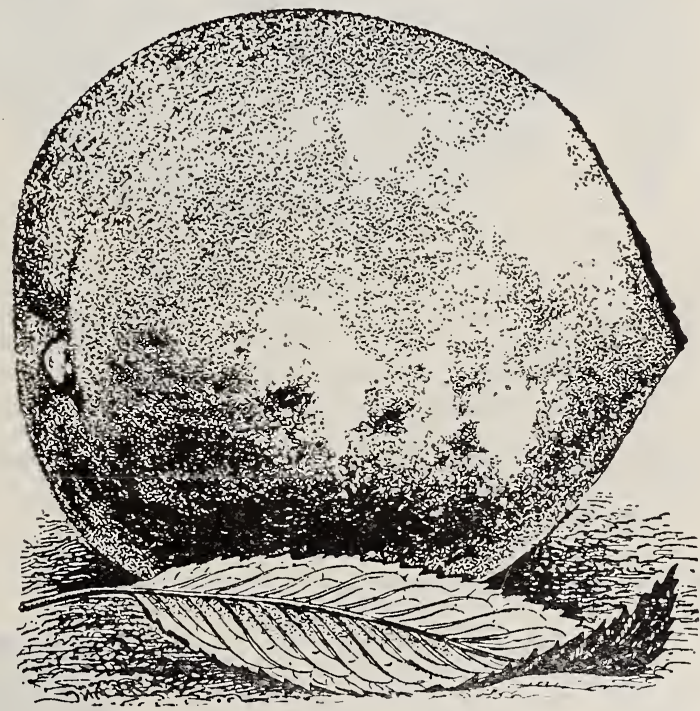

CARMAN PEACH

MOUNTAIN ROSE. A variety of very great value; fruit large, roundish; skin whitish, nearly covered with light and dark rich red; juicy, sweet, and extra îne quality; perfect freestone. One of the standard commercial varieties. August 25 th to September 1st.

CHAMPION. Fruit large, of beautiful appearance, flavor delicious, rich, sweet, juicy, skin creamy white, with red cheeks. A good shipper, beginning to ripen with the last of the Mountain Rose. The peculiarity of this handsome peach is the hardiness of its fruit buds. Is largely planted by commercial growers. September 1st to 5th.

CRAWFORD'S EARLY. The true Crawford's early, of which we have a large guaranteed stock, is a most valuable market peach. It is a magnificent, yellow-fleshed fruit, of large size and highly colored. This variety was almost extinct, but it has been revived better than ever. Many growers have been raising a small, yellow-fleshed peach and calling it Crawford's Early, by which they have done great injustice to this splendid fruit. Tree a moderate grower and extremely productive. September 5 th.

NIAGARA. Large, yellow, with red cheek; juicy and high flavored; flesh yellow; freestone. Season medium early, following quick upon Early Crawford. This is truly a fine peach, noted for its large size and fine appearance, but with us appears to be a shy bearer. At its home in western New York, it is regarded as a valuable commercial variety. Ripens just after Crawford Early.

REEVE'S FAVORITE. Large to very large; yellow, with beautiful red cheek, best of all in quality, but a shy bearer, and of doubtful value for the commercial grower in this section. September 10th. 


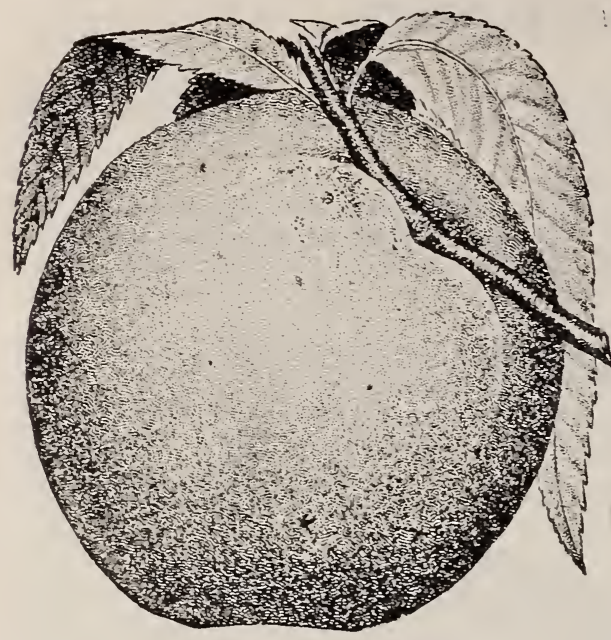

OLD MIXON PEACH.

OLD MIXON. This is a fine, large, exceedingly productive variety, succeeding well in all localities and well deserving of the high favor in which it is held as an orchard variety. Skin yellowish white with a red cheek; flesh white but red at the stone; tender, rich and excellent. Our strain of this variety is the best to be-had, and were grown from a tree more than fifty years old, now standing in a healthy condition on the ground of $\mathrm{J}$. W. Kerr of Denton, Md. September 10th.

BEQUETT FREE. Large; skin greenish white, blushed and marbled with red; flesh white and of fine quality. It is a certain and heavy bearer and the fruit is all large. Just about like the Elberta except it is white. September 10th.

BELLE OF GEORGIA. A large white peach with beautiful red cheeks, one of our most hardy and reliable bearers, and regarded as a most valuable, standard, commercial variety by all experienced growers. Tree a rapid grower and comes into bearing early. September 10 th.

"Grand for family or market, most reliable white fleshed peach known."

ELBERTA. Here is the King of Market Peaches! An exceedingly large, light-colored yellow peach with red cheek. Flesh yellow. This is truly a fine peach, noted for its large size and fine appearance. The tree is vigorous and very productive. No other peach has made such a name for shipping and none is cultivated more extensively. It is the ideal market peach, and a royal fruit. The fruit market has never yet had too many of this sort. A perfect freestone. Commercial growers have made more money on this variety than on all others. September 10th to 15 th.

STUMP. A large, roundish white peach with red cheek; a valuable commercial variety. There has been considerable confusion regarding this variety, some planters having a strain ripening with Old Mixon, but ours were grown from healthy bearing trees, ripening after Elberta. September 10th to 15th.

CRAWFORD'S LATE. A standard sort, of large size, considered by some the best of its season, and as a yellow fleshed peach, unequaled in quality. September 15th to 20th.

FRANCES. A large yellow peach ripening just after Elberta. By time the latter is done Frances is ready for shipment and this prevents the occurrence of a break in the succession and reaches the market at a time when peaches are in great demand. It is a very handsome peach. September 15th to 20 th.

"A very handsome and promising peach, especially for market." Ohio Exp. Station, Bulletin 170.

"Hardy, vigorous and productive, large, handsome and of good quality; ripens just after Elberta, which is a valuable point in its favor." - E. H. Riehl in Coleman's Rural World.

FOX'S SEEDLING. Medium to large; white flesh; skin creamy white, with bright red cheek; a very heavy bearer. One of the most profitable late white peaches grown.

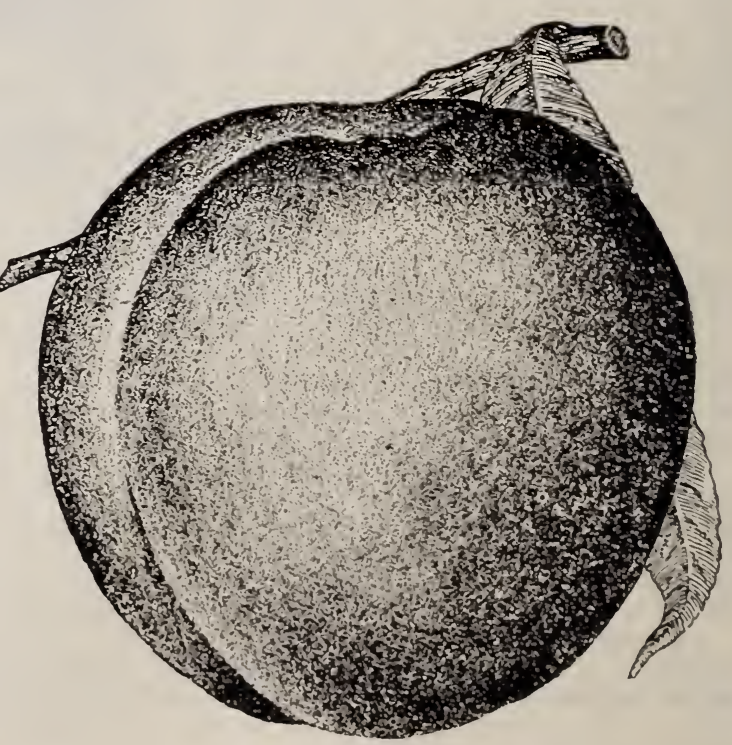

FRANCES PEACH As popular among late white peaches as is Mountain Rose among the medium early. September 25 th to October 1st. 
BRAY'S RARERIPE. "If you are located where peach buds are very liable to winter kill, plant some of these, for they are very hardy in bud, and need to be thinned. White with red on sunny side; freestone, flesh fine grained. Heavy bearer. September 25th to 30th." - L. E. Covert, New York.

I R O N MOUNTAIN. "Size large, shape oblong or egg shape, color pure white, sometimes having a slight blush. It is perfect freestone and has as good quality as any white peach ever grown. Season September 20th to October 10th, according to season and soil." -J. H. Black \& Son.

We have not fruited this variety.

CHAIR'S CHOICE. Much like Late Crawford, but a week later in ripening, and like Late Crawford, needs a rich, strong soil to do its best. In western New York, these varieties are

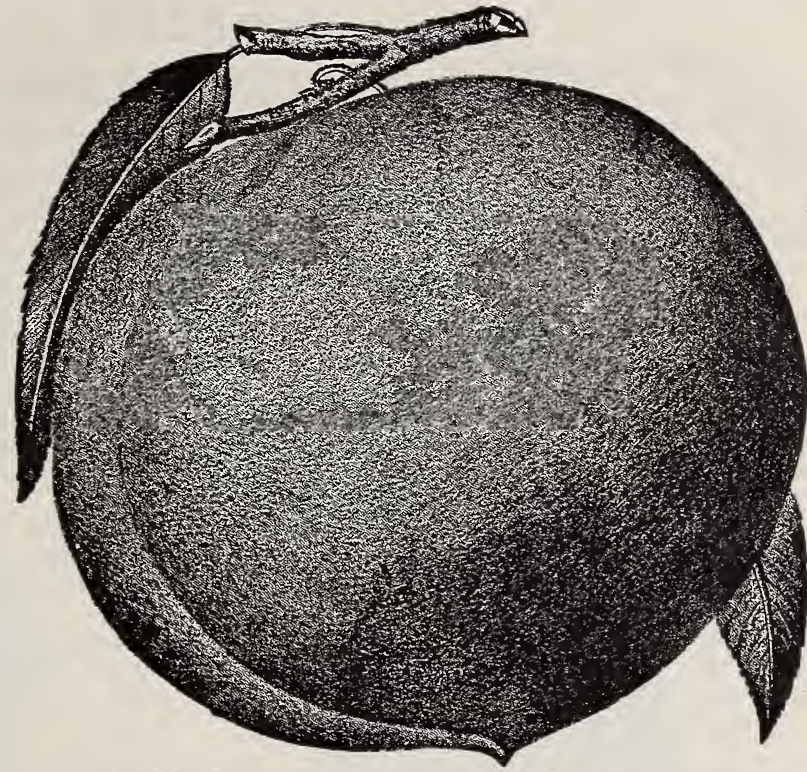

STEVENS' RARERIPE regarded as among the most profitable commercial sorts, but they are generally unprofitable in this section. September 25th.

WILLETT. This peach we have not fruited, but it is described as a very large yellow peach of the Late Crawford type. Our trees are the second generation from the original tree. September 25th.

"Its hardiness in bud, beauty, excellent shipping quality, and special adaptability for all purposes make it one of the most promising varieties for the commercial grower." -Dept. of Agriculture.

"It is more than good."-W. L. McKay, New York.

SMOCK. Medium to large light orange yellow, with red cheek; flesh yellow, rich, excellent quality. October 1st.

MATTHEW'S BEAUTY. This new and valuable peach is a cross between Elberta and Smock, showing a parentage of both. The fruit is large, shaped similar to Elberta, but a little longer. Skin a beautiful yellow, streaked with red; flesh yellow, firm and of excellent quality. An annual and prolific bearer, with shipping qualities unsurpassed. Ripens about three weeks after Elberta, which it exceeds in quality. The above is as it has been described to us. We have not fruited it ourselves.

STEVEN'S RARERIPE. Large, white peach with red cheek. Tree hardy in bud and a good bearer. Steven's is regarded by growers in the Hudson River section as one of the best commercial varieties, and has been planted largely by some of the best posted growers in Connecticut the last few years. We fruited this variety this season and thought very highly of it. It was certainly best in quality of any peach we ever saw of its season. October 1 st to 5 th.

"High quality, heavy and regular bearer."-L. E. Covert, New York.

"The favorite variety in the Hudson valley to follow Elberta, ripening a week or ten days later. A good shipper. Is often held in cold storage eighteen to twenty-one days without loss, when its fine appearance insures top prices."-E. W. Barnes, New York.

SALWAY. A large round deep yellow peach with dull red cheek; flesh firm and rich. In this latitude needs to be planted on early light soil. October 1st to 5th.

"Produces more blossom buds than most varieties which are winter hardy, nearly always needs thinning of fruit."-E. W. Barnes, New York.

"Produces a crop when other varieties fail." - L. E. Covert, New York.

EMPEROR. Very large, yellow fleshed, skin a beautiful yellow with red cheek.

PLEASE REMEMBER when you write, to send us the names of your friends who are interested in fruits. 


\section{A P P L E S}

APPLES FOR HOME USE. Every owner of a home in the United States should grow Apples enough for his own use. By careful selection of varieties and by proper and intelligent culture, a succession of fruit can be had covering nearly the entire year and no fruit is so luscious as that picked fresh from one's own trees.

APPLES FOR PROFIT. The planting of commercial orchards is simply a business proposition. It can be made to pay better than almost any line of out-door work, provided the grower does his work thoroughly, persistently and intelligently.

\section{W A R F A P P L S}

There is an increasing demand for apples upon dwarf stocks by those that wish to grow fancy fruit. We have apples on Doucin stock upon which the tree ultimately grows to be the height of a good-sized peach tree, and which are said to bear freely at five or six years of age. These stocks have not been fully tested yet and there is a difference of opinion as to their value. For those who aim at large yield as first consideration, we recommend standards, but for those who wish to grow the best possible quality of fruit, these dwarf trees we believe to be worthy of consideration.

Think of the difference of spraying, thinning and picking from trees the size of a large peach tree and a full-grown standard apple tree. It is evident that spraying, thinning and picking can be done with greater thoroughness and more cheaply than would be possible with standards.

Our orchard plantings of these trees comprise several thousand trees and are probably the largest in the United States, and last summer at three years they bore specimens and now have a great many fruit buds for another year.

Varieties and price on application.

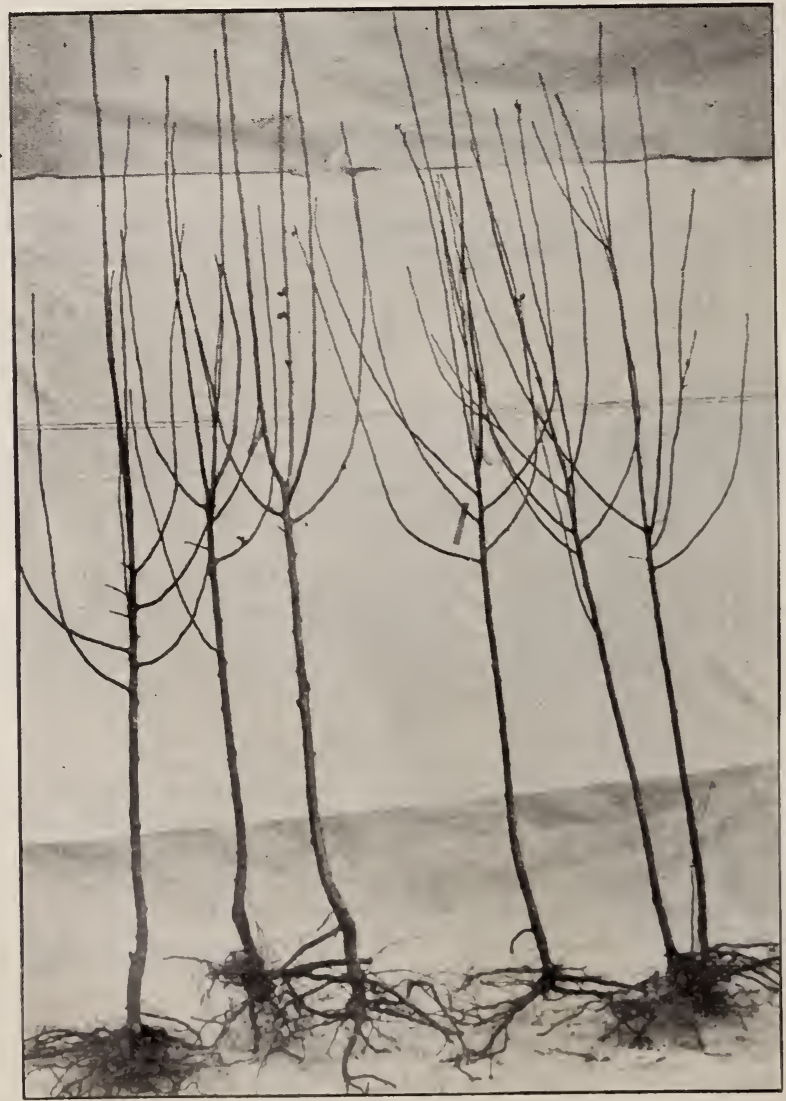

VARIETIES. For family use it would be safe to plant any of the sorts named in this catalogue. In selecting varieties be governed by the experience of other orchardists in your locality, and by the suggestions of the nearest Experiment Station. Plant young trees of staple, well-tried kinds, that succeed in your vicinity and you will be safe. Plant sparingly of new and untried varieties until they have stood the test of time.

There is not much choice between late fall and early spring planting. Either will succeed if the earth is thoroughly firmed about the roots.

WHEN YOU PLANT. At least three-fourths of the previous year's growth should be removed from the tree at planting. The lower branches should be the longest; each cut should be made just beyond a bud. Should the top be spreading, cut to an inside bud, and if it is upright cut to an outside bud. This is of great importance, and should be carefully followed.

This photograph shows three each of two grades of our Apple trees. The three at the left are our $\frac{3}{1}$ inch and up grade, the three at the right our to inch grade. Notice the handsome root system with which our trees are equipped. 


\section{GENERAL LIST OF APPLES SUMMER APPLES}

EARLY HARVEST. Large, pale yellow, fine flavor. Good bearer.

GOLDEN SWEET. A large yellow Apple, very sweet and good. A strong grower and good bearer.

RED ASTRACHAN. Large, crimson, rather acid, juicy, fine for cooking. Tree hardy, free grower and good bearer. Highly esteemed for its fine appearance, earliness and hardiness.

SWEET BOUGH. Large, pale yellow, sweet and juicy. An abundant bearer.

YELLOW TRANSPARENT. Medium, pale yellow, tender, juicy, sub-acid. Bears very young, often the third or fourth year.

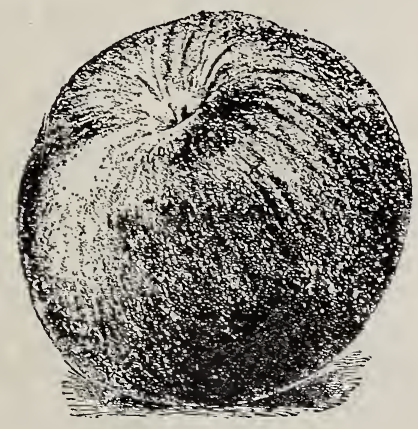

GRAVENSTEIN

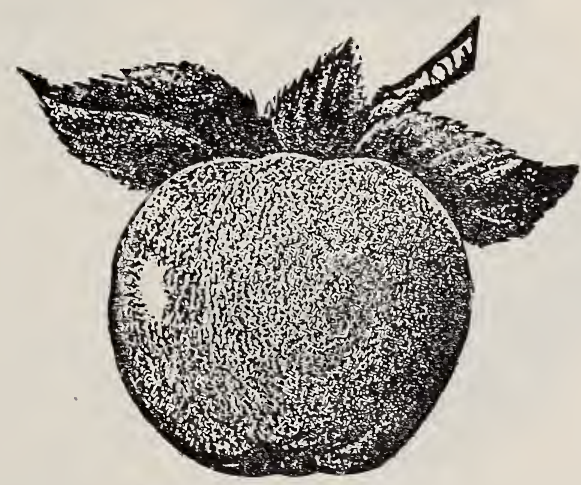

YELLOW TRANSPARENT

\section{A U T U M N A P P L E S}

DUCHESS OF OLDENBURG. Large, streaked red and yellow, juicy, sub-acid. Tree a vigorous grower and a young and abundant bearer.

FALL PIPPIN. Large, yellow, tender, one of the most valuable. Excellent for cooking. Succeeds in nearly all sections.

FAMEUSE OR SNOW. Medium size, deep crimson, flesh snowy white, tender, highflavored. Very hardy, productive and popular.

GRAVENSTEIN. Large, striped red. A popular variety.

MCINTOSH RED. Large, dark red, of Fameuse type. A handsome Apple of fine quality. Tree vigorous and hardy.

POUND SWEET. Large, yellow, sweet and rich; valuable.

WEALTHY. Large, red, streaked with white, excellent quality. Tree is healthy, hardy and productive.

WOLF RIVER. Large, handsome red, flesh white and fine quality, sub-acid. Tree very hardy and productive.

\section{W I N T R A P P L E S}

BALDWIN. Too well known and popular to need description.

BELLFLOWER. Large, yellow, with pale blush, very tender and juicy. An old favorite which has always been popular; good keeper. November to April.

BEN DAVIS. Fruit medium to large; roundish, skin striped and almost covered with red. This variety is being planted more and more each year by those that have fruited and know it, on account of its being such a young and regular bearer of handsome, latekeeping fruit that is remarkably free from fungii, and sells for as much or more than vari. eties of better quality.

BISMARCK. Tree short, stocky growth, with thick, healthy foliage, hardy and productive; is doing well in nearly all places. Fruit large, handsome, yellow shaded and covered with red; tender, sub-acid, good for both dessert and cooking. Its most remarkable characteristic is its early fruiting habit; two-year trees seldom fail to produce fruit. Late fall and early winter.-Originator's Description. 


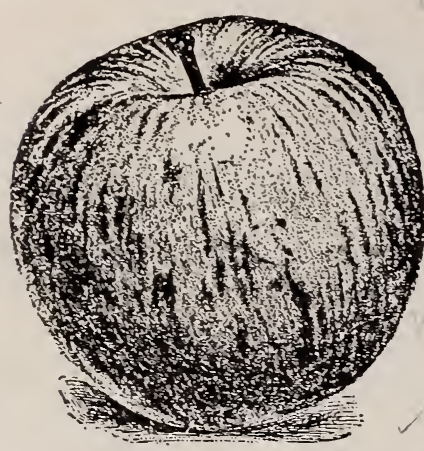

SUTTON BEAUTY

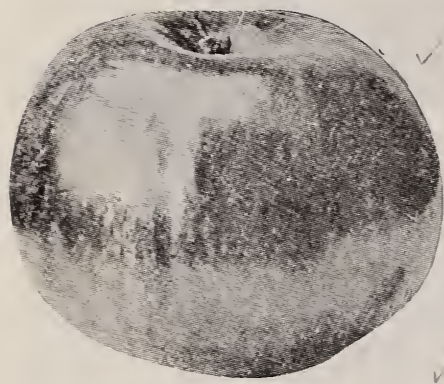

OPALESCENT

FALLAWATER. Very large, handsome, yellow with red cheek, mild, sub-acid. Tree a strong grower, young and abundant bearer.

GANO. An Apple with a very great future. A fine commercial sort. Very hardy. A half brother to Ben Davis, though of better quality. Very richly colored, uniform in size; keeps until March; rapid grower, fruit very handsome, flesh pale yellow, mild, sub-acid, good. Large, good marketing and keeping.

GOLDEN RUSSET. Medium, dull russet, juicy and high flavored. Hardy and good bearer and a fine keeper.

GRIMES' GOLDEN. An Apple of the highest quality, medium to large size. Rich golden yellow. Hardy, vigorous and a very productive and profitable variety, bearing young.

HUBBARDSTON NONSUCH. Large, striped yellow and red. Good grower and bearer.

JACOB'S SWEET. A large, handsome, roundish Apple; yellow with red cheek; strong grower and heavy bearer. One of the best sweet Apples.

JONATHAN. Perfectly hardy and is productive in all soils, which makes it one of the most desirable Apples. Fruit of medium size, very regularly formed. Skin thin and smooth; yellow ground almost covered with lively red stripes deepening into dark red in the sun. Flesh white, very tender and juicy, with a vinous flavor. Very valuable for home use or market. Oct. to Jan.

KING. A fine New York Apple, of largest size and best quality; red, showy; tree vigorous and hardy; bears early: Many Apples of poor quality are sold at high prices to uninformed buyers just because they are marked "Kings." November to January.

NEWTOWN PIPPIN. Of medium size, greenish yellow; of fine quality and a good keeper. December to May. NORTHERN SPY. Large, striped red, juicy, rich. Tree a rapid grower and a great bearer. OPALESCENT. Color light, shading to very dark crimson with many yellow dots; skin smooth, susceptible of a very high polish, reflecting objects like a mirror, flesh yellowish, tender, juicy and good. The original tree has never failed to produce frum a moderate to a full crop. It is not only a beauty, but all right for size, quality and productiveness, qualities rarely combined in one variety. Season December to March.

PECK'S PLEASANT. Large, pale yellow, very rich, with flavor like a N'ewtown Pippin. Tree erect grower and good bearer.

RHODE ISLAND GREENING. A well known and justly popular variety. Large, greenish yellow, tender, juicy and rich, with rather an acid flavor. One of the very best for cooking. Tree grows strong and spreading and an abundant bearer; an excellent keeping Apple.

ROME BEAUTY. Large, yellow, bright red, hands,ine, first quality, moderate grower, early bearer.

ROXBURY RUSSET. Popular on account of productireness and long keeping.

SUTTON BEAUTY.

Medium to large, handsome yellow, striped crimson. Flesh tender, excellent quality, remarkable keeper. Tree free growing. Productive. This is rapidly taking a leading place as a market Apple.

Y O R K IMPERIAL. Medium size, oval, angular, skin greenish yellow, nearly covered with bright red, flesh crisp, tender and juicy, aromatic; ar enormous bearer and hangs well on the tree; also a good keeper. retaining its flavor to the last. December to April.

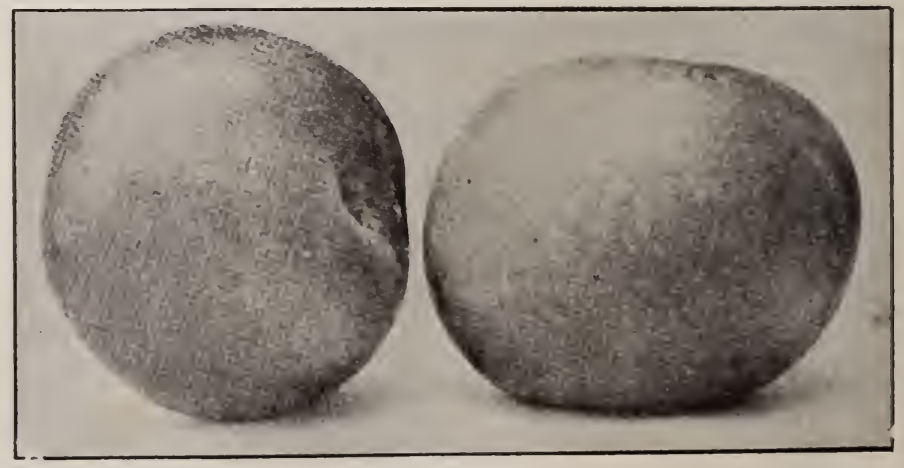

RHODE ISLAND GREENINGS 


\section{R A B A P P L E S}

Crab Apples are more popular and more profitable each year. They should be given liberal consideration with all other fruits suitable to this climate.

HYSLOP. Dark red covered with thick, blue bloom; round, yellow flesh, sub-acid, tender, large. Good for cooking and cider. Hardy.

RED SIBERIAN. Small, tree a good grower; bears early; handsome.

TRANSCENDENT. Medium to large; roundish, oblong, slightly ribbed, golden yellow with red cheek, with thin white bloom, flesh yellow, crisp, sub-acid, pleasant. Early Fall. Best of its class.

\section{P E A R S}

STANDARD PEARS should be planted 20 feet apart. They will grow on almost any soil, provided the sub-soil is not too wet. Whenever this is the case the ground should be thoroughly underdrained. In very poor soil a moderate top-dressing of manure in the Fall will be of advantage. When a tree is assailed by the blight, cut off the part affected several inches below all appearance of the disease.

BARTLETT. Large; buttery, rich-flavored, melting; good grower; flesh white, fine-grained, luscious. More generally popular than any other Pear. August and September.

BEURRE CLAIRGEAU. Large, melting. Tree a stout grower, regular and reliable in bearing. October and November.

BEURRE D'ANJOU. Large, juicy, ·melting, fine grained. Tree vigorous, productive, reliable; a regular and annual bearer. Early winter.

CLAPP'S FAVORITE. Large, attractive, red-cheeked,

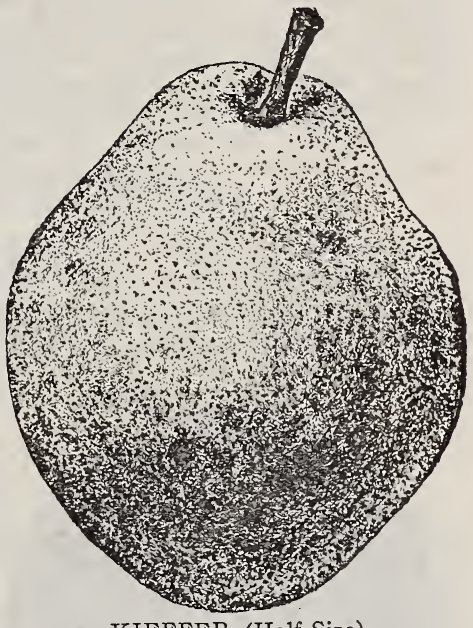

KIEFFER (Half Size)

good. Resembles Bartlett, but is earlier and without its musty flavor. Very desirable.

DUCHESSE D'ANGOULEME. Very large, greenish yellow, with patches of russet and a dark red cheek. Strong grower and a good bearer. Attains greatest perfection when dwarfed on quince root. October and November.

KIEFFER. Tree vigorous, blight-proof; an early, profuse and regular bearer. Fruit large, rich yellow, tinged with red; flesh whitish, a little coarse, juicy, with a marked musky aroma. Excellent for canning and market. Best when house-ripened.

KOONCE. A very popular early variety. Fruit medium to large, yellow, one-half nearly covered with red. Does not rot at the core. Tree vigorous, free from blight, upright, handsome grower. Very productive and a good shipper.

LAWRENCE. Medium sized, light yellow; sugary, good; reliable and productive. December to January.

LOUISE BONNE DE JERSEY. Tree especially desirable as a dwarf; vigorous, very productive; fruit medium size, pyriform, somewhat one-sided; skin smooth, glossy, pale green in shade, but brownish red

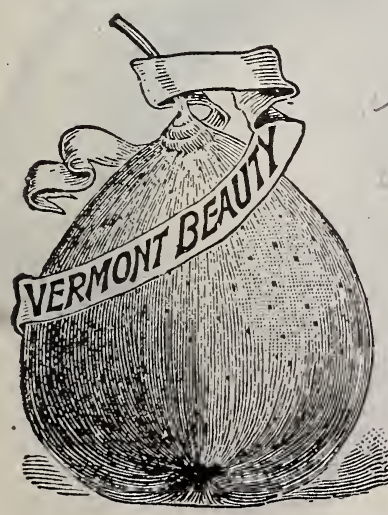
in the sun; flesh greenish white, very juicy, with a rich, excellent flavor. September and October.

SECKEL. Small, rich, yellowish; one of the best and highest flavored Pears known. Very productive. September and October.

SHELDON. Medium to large; yellow and somewhat russet; a fine grower and productive. One of the best. October.

VERMONT BEAUTY. This beautiful and valuable Pear is very hardy, having endured extremely cold weather, and has never lost a bud from either cold or blight. The growth is vigorous, leaves free from blight, the tree an annual and abundant bearer. In quality the fruit approaches nearer that most delicious of Pears, the Seckel, than any other Pear on the market. It is of full medium size, yellow, covered on the sunny side with bright carnine-red, making it exceedingly attractive and handsome; flesh melting, rich, juicy, aromatic. Ripens with and after Seckel. Is one of the most profitable market Pears and one of the best for home use. 
WILDER EARLY. A good growing, good keeping, good shipping, superior flavored, very early handsome Pear. It holds its foliage well, and thus far has been free from blight or other disease. Medium size, handsome, of high quality; solid and does not rot at the core. Tree bears young.

\section{W A R F P E A R}

DWARF PEARS should be planted 12 feet apart. At the time of planting, and every spring thereafter, they should be thoroughly pruned, shortening in the current year's growth about one-half, aiming to form a round and well-proportioned head. The ground should be well cultivated, enriched by a top-dressing of manure in the autumn, and well mulched in the spring. Pears grown on standards or dwarfs should never be allowed to ripen on the tree. Summer and autumn varieties should be gathered about ten days before they are ripe, and winter Pears before frost sets in.

We can furnish the following varieties of Dwarf Pears: Wilder, Clapp's, Bartlett. Seckle, Duchesse d'Angouleme, Vermont Beauty, Louise Bonne and Lawrence.

\section{J A P A N PL U M S}

The value of this race of Plums is no longer in doubt. Trees of tremendous vigor, they come into bearing two and three years after planting and in such variety and season

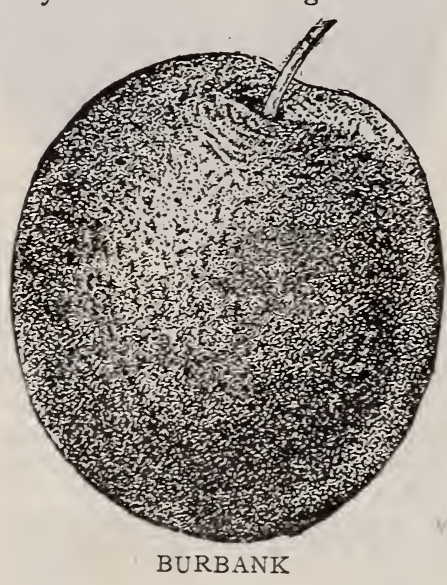
of ripening as to cover a period of three months with a daily supply of luscious Plums. The trees grow so quickly, produce so abundantly, and the fruit is so large and fine that it is possible to produce these delicious Plums as abundantly and cheaply as our most common apples. They are much less liable to the black-knot than the European varieties, and are never seriously injured by the curculio. They are beautiful in appearance, superior in quality, and many of them will keep from ten days to two weeks after picking, a great point in favor of their marketing. Like the peach, the trees grow so fast and bear so heavily that they have a tendency to be short lived. Growers should keep planting some trees each year so as to keep up the supply. The trees produce so abundantly that some have feared a glut of the fruit and planting for the last year or two has fallen off, but we predict larger returns from the fruit in the next few years for those who stick to them and keep planting.

OCTOBER PURPLE. Luther Burbank speaks of this Plum thus: "October Purple is a splendid grower, ripens up its wood early to the tips; bears every season; fruits all over the old wood on spurs, instead of away out on the branches like many other kinds. Fruit very uniform in size. It is a superb variety."

CLIMAX. Professor H. E. Van Deman, in The Rural New Yorker says: "Climax is about the largest Plum I have ever seen, except Kelsey. The shape is oval and quite regular. In color it is a deep reddish purple, very rich looking and attractive. The flesh is yellow and firm until fully ripe, when it becomes melting and juicy. It is almost a freestone. The flavor is a pleasant sub-acid, with a peculiar aroma that is deliciously refreshing. The quality is much better than that of any early Plum I know, and is good compared with any kind. It ripens before Willard or Red June."

A B UNDANCE. One of the oldest and best known Japanese varieties; hardy and productive. Fruit large, lemon yellow, with heavy bloom; good quality. August.

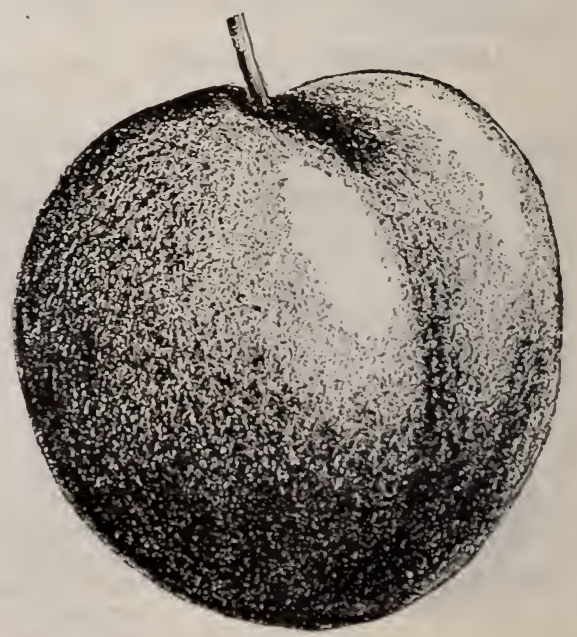

OCTOBER PURPLE 
BURBANK. The best and most profitable among growers for market; ripens seven to ten days after Abundance. Tree hardy, sprawling, vigorous grower, unequaled in productiveness; bears young. Fruit large, excellent quality; cherry red, with lilac bloom. August.

RED JUNE. A vigorous, hardy, upright, spreading tree, as productive as Abundance; fruit medium to large, deep vermillion-red, with handsome bloom, very showy; flesh light lemon-yellow, slightly sub-acid, of good and pleasant quality; half cling; pit small. Ripens a few days after Willard, and is the best in quality of any of the early varieties.

SATSUMA. A purple-fleshed Plum of very vigorous growth, with rank, dark green foliage; enormously productive of fruit; large; skin dark purplish red, mottled with bluish bloom; flesh firm, juicy, dark red or blood color, well flavored. Pit very little larger than a cherry stone. Fruits at two or three years of age. Unexcelled for canning and preserving, and considered by some to be the most valuable of Japan Plums. Midseason to late.

\section{GENERAL LIST OF EUROPEAN PLUMS}

A rich, strong soil best suits the Plum. Good cultivation and regular fertilizing are required. If "black knot" should appear, cut it out at once. The curculio must be closely watched during the formation of the fruit. Every morning jar down on sheets, both insects and stung fruit and destroy them.

BEAUTY OF NAPLES. A new variety of the highest promise; large; color greenish yellow; flesh firm, juicy, very fine-flavored. Tree very hardy and prolific. Middle of September.

BRADSHAW. A very large and fine early Plum; dark violet-red; juicy and good. Tree erect and vigorous; very productive. Valuable for market and home use. August.

GERMAN PRUNE. Fruit oval, nearly two inches long, of good quality; hangs well on tree and is firm and sweet.

LOMBARD. Very productive; one of the best and most reliable for market. Violet-red, of medium size; flesh juicy and good; adheres to stone; rich and tender. A popular hardy variety, ripening in August.

GRAND DUKE. A valuable addition to late Plums; as large as the Bradshaw, of same color; free from rot; ripening latter part of September.

IMPERIAL GAGE. Fruit medium to large, oval, green, inclined to yellow when ripe; rich, juicy, excellent in quality and of deserved popularity in a general collection.

NIAGARA. Unsurpassed for beauty and productiveness as well as great hardiness of tree, with foliage so perfect as to contribute in an essential degree to its health. Fruit large, oval, often with a slight neck; skin reddish purple; flesh yellow, juicy and good. Its beauty as a market sort is unsurpassed.

REINE CLAUDE. Large; greenish yellow, spotted with red; firm, juicy, sugary, of fine quality; very productive. September.

SHROPSHIRE DAMSON. A Plum of fine quality, as free from the attacks of the curculio as the common Damson, and of same color. The flesh is amber-colored, juicy and sprightly.

\section{H E R R I E S}

There are few more desirable trees than the Cherry. It may be planted near the street or used ornamentally for avenues, and it will produce an abundance of delicious fruit. This may be eaten out of the hand, preserved, or will find a very ready market at highly profitable prices, for shipping, canning, etc. The trees thrive in any welldrained location. The Duke and Morello, or acid varieties, are thoroughly hardy. The Heart and Bigarreau, or sweet sorts, will successfully resist very cold weather and may be grown in most places.

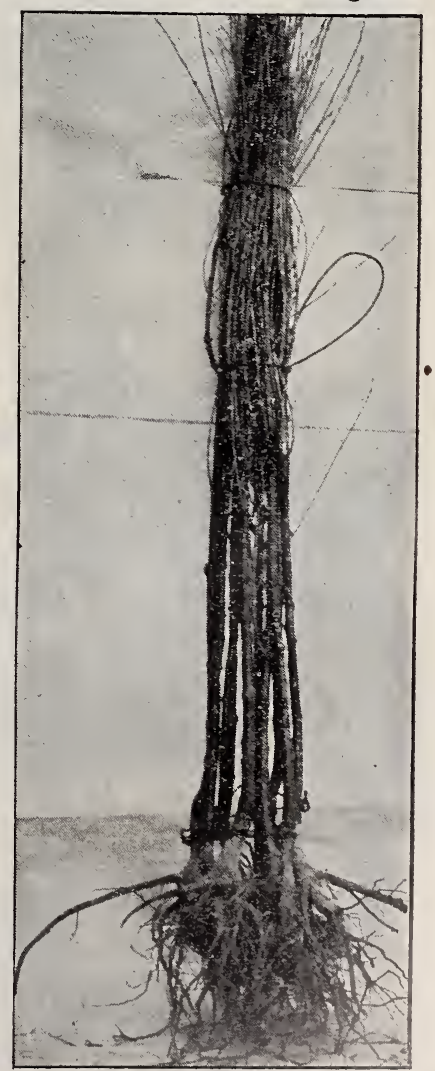

This shows a bunch of 10 of our first-class $3 / 4$ inch grade of Sour Cherry Trees. 


\section{GENERAL LIST OF CHERRIES HEART AND BIGARREAU CHERRIES}

BLACK EAGLE. Large, black; very tender, juicy, rich and high flavored; tree vigorous, productive. July 1st to 15 th.

BLACK HEART. Black Ox-heart. A very old variety. Fruit medium-sized, heartshaped, rather irregular; skin glossy, deep black; flesh tender, juicy, sweet. Tree a rapid grower, hardy and productive. Early July.

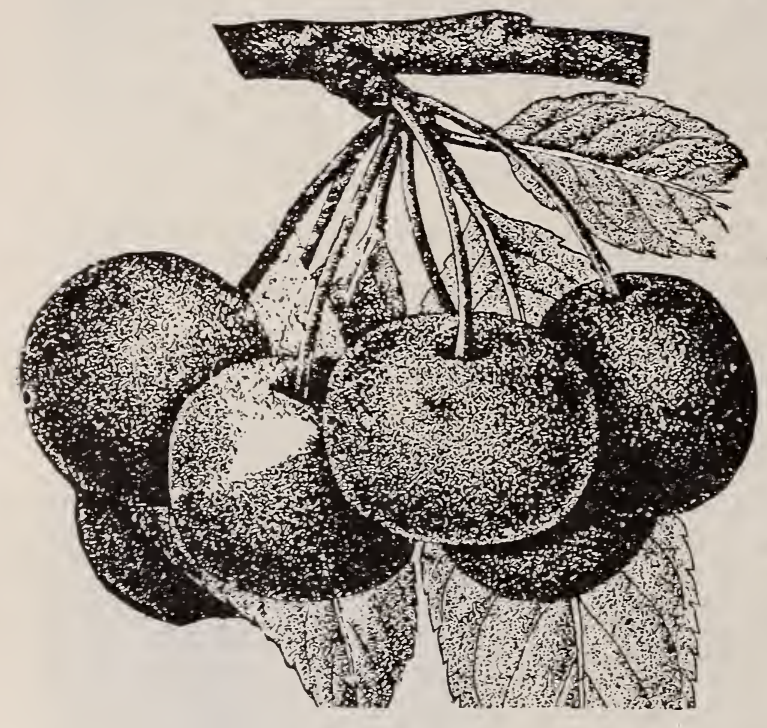

WINDSOR

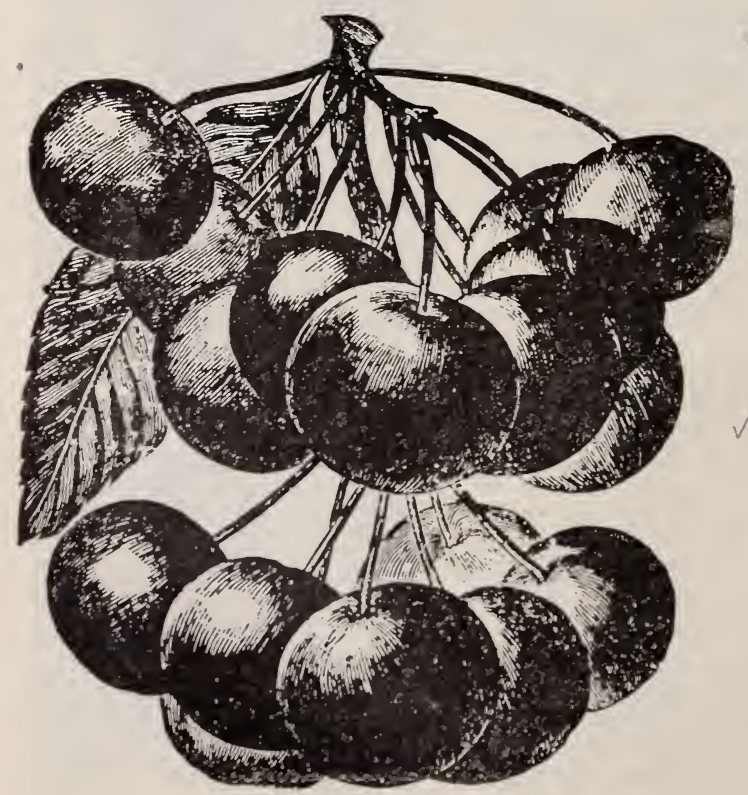

EARLY RICHMOND
BLACK TARTARIAN. Very large, bright purplish black; half tender, juicy, very rich, excellent. Vigorous and productive. Last of June or July. A general favorite.

GOVERNOR WOOD. Very large, rich light yellow, with red cheek; juicy, sweet, one of the very best. Late June.

NAPOLEON BIGARREAU. V e Y large, pale yellow or red; very firm, juigy and sweet; vigorous and very productive. One of the best. Early July.

SCHMIDT'S BIGARREAU. Fruit of immense size, rich, deep black; flesh dark, tender, very juicy, with a fine flavor; bears abundantly.

WINDSOR. New; originated in Canada. Fruit large, liver colored; flesh remarkably firm and fine. Tree hardy and very prolific. A valuable late variety for market and family use.

\section{DUKE AND MORELLO CHERRIES}

ENGLISH MORELLO. Medium to large, blackish red; rich acid, juicy, good; very productive.

EARLY RICHMOND. This is a hardy Cherry, fruiting on young trees soon after planting and bearing regularly every year enormous loads of dark red fruit that does not rot upon the trees and can be left without picking longer than most varieties. Unsurpassed for canning and profitable for market. Ripens through June.

LA R GE MONTMORENCY. The most popular of all hardy Cherries for market and home use. This Cherry is planted largely. The fruit is in great demand and sells at fancy prices. Montmorency has been growing in popularity all over the country each year, so that it has been almost impossible to grow trees fast enough to keep up with the demand. It is of large size, light red in color, stem rather short. The tree is very hardy and a vigorous grower. The trees bear fruit soon after planting. 
MAY DUKE. Large, red; juicy and rich; an old, excellent variety; vigorous, productive. June 15th.

OSTHEIM (RUSSIAN CHERRY). Dark red. Early to middle of July. Imported from St. Petersburg, Russia. In the severest winters of Minnesota found to be hardy. Fruit large, roundish. Flesh liver color, tender, juicy, sub-acid, and when fully ripe nearly sweet. Tree of slender growth.

\section{Q U IN C E S}

The Quince is of late attracting a good deal of attention as a market fruit. Scarcely any fruit will pay better in the orchard. The tree is hardy and compact in growth, requiring but little space, is productive, gives regular crops and is much sought after for canning for winter use. When put up in the proportion of about one quart of Quinces to four quarts of other fruit, it imparts a delicious flavor.

BOURGEAT. A golden prolific variety of the best quality, ripening shortly after Orange and keeping until midwinter. Tree a remarkably strong grower, surpassing all others and yielding immense crops, fruiting at three or four years in nursery rows; leaves large, thick glossy, so far free from blight and disease. Fruit of largest size, round; rich, golden yellow, smooth, very tender when cooked; has been kept till February in good condition.

APPLE, OR ORANGE. Large, roundish; bright golden yellow; cooks tender and excellent; valuable for preserves or flavoring. Very productive; the most popular and extensively cultivated of the old varieties.

CHAMPION. Fruit very large, fair and showy, cooks as tender as an apple, and without hard spots or cores; flavor delicate, imparting an exquisite taste and odor to any fruit with which it is cooked. Tree handsome, surpassing other varieties in this respect, bears abundantly while young.

\section{U L B E R R I E S}

The Mulberry is valuable not only on account of its fruit, but as a desirable shade tree. It is of easy culture, requiring little or no pruning.

DOWNING'S EVERBEARING. Fruit large, blue-black, juicy, rich, sugary, with a sprightly vinous flavor. Tree vigorous and productive, continuing in bearing about three months. A large-growing and desirable shade tree.

RUSSIAN. Very hardy, vigorous grower. Much used for hedges and windbreaks; valuable for feeding silk worms. Fruit of small size.

\section{N U T T R E E S}

WALNUT, BLACK. A native tree of large size, beautiful foliage. Very valuable for its timber. A rapid growing tree, producing a large, round nut of excellent quality.

WALNUT, JAPAN. (Cordiformis). A tree of great vigor, perfectly hardy. Handsome form, immense green leaves, bearing heart-shaped, pointed nuts in clusters of twelve or fifteen each at tips of previous season's branches. Meat sweet and of superior quality. Tree commences bearing when young.

CHESTNUT, JAPANESE. 'Seedling. These are among the most valuable and begin to bear at two or three years of age, the nuts measuring 4 to 5 inches in circumference, and running three to seven in a burr. They ripen very early and do not require frost to open the burrs.

CHESTNUT, SPANISH. Seedling. A handsome, round-headed tree of rapid growth, yielding abundantly large nuts of good quality.

CHESTNUT, PARAGON. Grafted. Tree very vigorous, and upright grower, hardy and productive. Nuts large, kernel fine-grained, sweet and of good quality.

JAPANESE MAMMOTH CHESTNUT. Grafted. Tree of dwarf habit, bears very young and abundantly of very large nuts. Imported direct from Japan.

DEAR SIRS:

Orange Co., N. Y., April 17, 1908.

The trees came yesterday in the finest shape of any I ever had sent me. (Eight days on road, too.) Obliged for premiums. 


\section{G R A P E S}

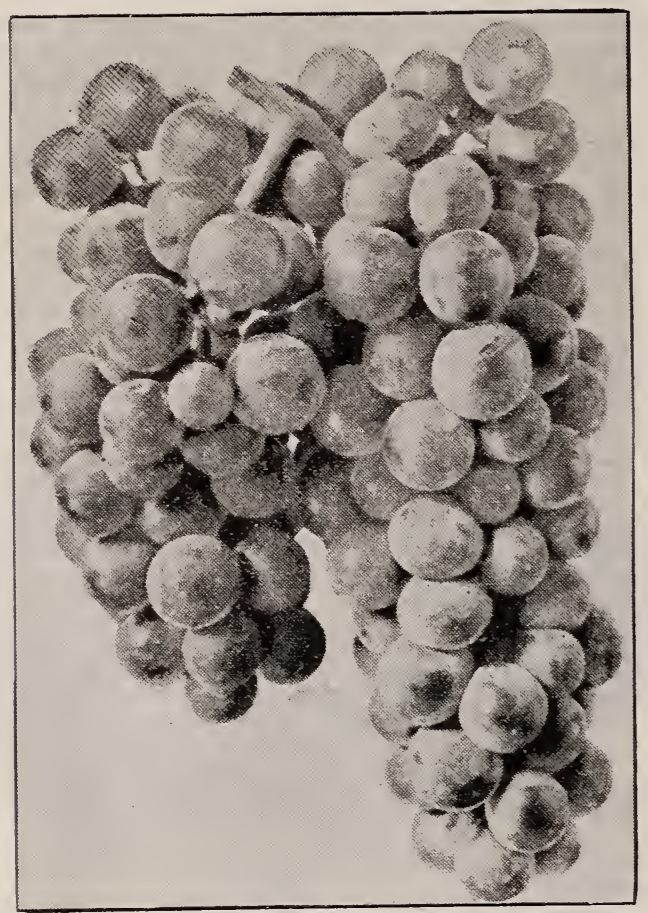

CAMPBELL'S EARLY

Grapes will flourish and bear abundantly on almost any good, dry soil, especially if the vines are trained against a building. Soil should be well-drained and there should be a free exposure to sun and air. Because some of the more tender varieties will not grow, it is not necessary to conclude that others will not succeed. There are kinds adapted to almost every locality that may be grown on a very cheap and simple arbor, even on single poles or stakes. Annual and careful pruning is essential to the production of good Grapes; this should be done in winter when the vines are dormant.

BRIGHTON. In color, form of bunch and berry, resembles Catawba, combining the sprightliness of that variety with the richness and sweetness of Delaware; vine vigorous, hardy, productive.

CAMPBELL'S EARLY. Seedling of Moore's Early. A vigorous, hardy grower, with healthy and abundant foliage which resists mildew. Bears profusely large clusters of fruit, usually shouldered and compact. Berries nearly round, black, with blue bloom; skin thin but tenacious; flesh rather firm, tender, rich, sweet, slightly vinous, with no foxiness or acidity. Ripens early, and hangs on the vine six weeks after ripening. We believe it has come to stay.

CONCORD. Black; bunch large, shouldered, compact; berries large, tender-skinned, juicy, sweet; vine strong growing, hardy, productive. The standard market Grape of America.

DELAWARE. Small, light-red, thinskinned; very juicy, sweet and sprightly. Slow growing and tender; requires a rich soil and a favorable situation on the south side of a building to succeed well; of the highest quality when properly grown.

EATON. Bunch and berries very large, covered with a heavy blue bloom; pulp tender, separating freely from the seeds, very juicy; vine healthy, hardy and productive.

GREEN MOUNTAIN. New. Found growing in a garden on the side of the Green Mountains in Vermont, at an altitude of 1,400 feet, where it ripened its fruit perfectly. Vine strong,vigorous, healthy, very hardy and productive. Bunch long, compact, shouldered. Color green or greenish white; skin thin; pulp exceedingly tender and sweet: Very early, being three weeks earlier than Concord.

MOORE'S DIAMOND. Vine vigorous, with large, dark, healthy foliage, prolific,

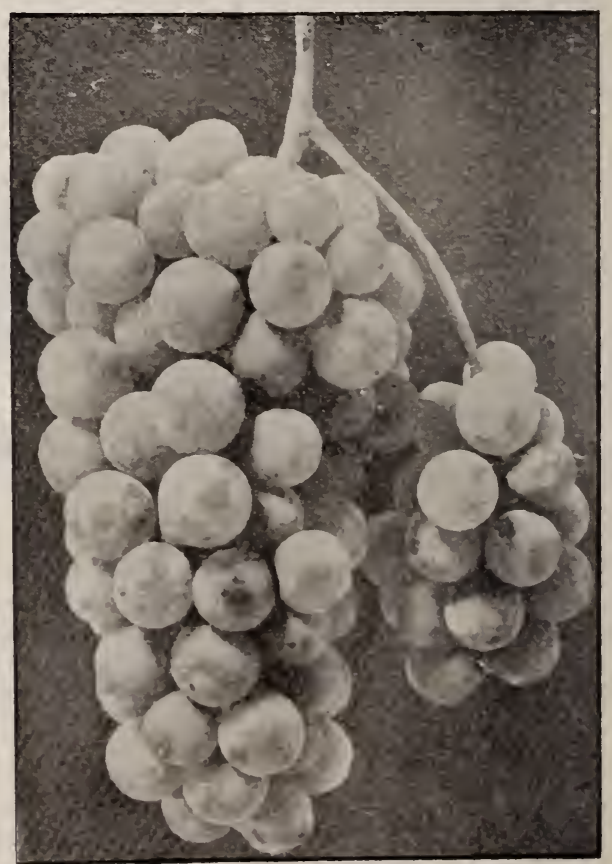

GREEN MOUNTAIN 
producing large, handsome, compact,slightly shouldered bunches, of delicate greenish white, with rich yellow tinge. Its desirable characteristics are earliness, hardiness, healthfulness and good quality.

MOORE'S EARLY. One of the best very early Grapes. A seedling of Concord, which it equals in vigor and hardiness of vine, but ripens ten days or two weeks earlier than that variety. Bunch large; berry round and large, black, with a heavy blue bloom; quality good.

NIAGARA. One of the best known white Grapes. A splendid table Grape. Mid-season.

WORDEN. A seedling of Concord; ripens a few days earlier, has a larger berry, and a larger and more compact bunch; hardy and healthy; black, of fine quality and very desirable.

WYOMING RED. A decidedly fine, early red Grape. Bunch and berry double size of Delaware, of same color, with similar flavor. Ripens a week or ten days before Concord.

\section{U R R A N T S}

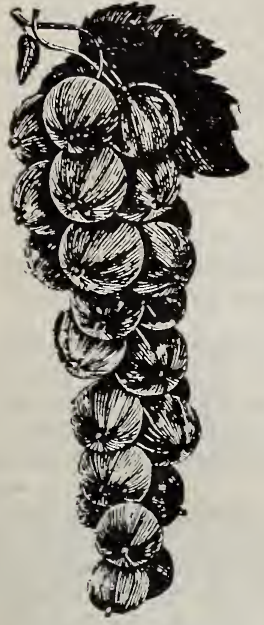

FAY'S PROLIFIC

CURRANTS AND GOOSEBERRIES should be planted on good soil, which must be kept rich and well worked. Few plants will live under such neglect as these generally receive, and very few so thoroughly repay good and proper treatment. Trim out the old wood as soon as it begins to decline, and shorten all the young shoots to keep the bushes in good shape. Sprinkle ashes around the roots occasionally. to keep the borers away. The currant worm may be destroyed by sprinkling the bushes with powdered white hellebore while they are wet with dew. In some instances it may be necessary to repeat this process, but the trouble and expense of exterminating the worms is trifling if the powder is applied as soon as the worms appear.

WILDER. A remarkable variety of great popularity both for table and market. One of the strongest growers and most productive. Bunch and berries very large, bright, attractive red color, even when dead ripe; hangs on bushes in fine condition for handling as late as any known variety. Compared with the celebrated Fay's, is equal in size, with longer bunch, better in quality, with much less acidity, ripens at same time, continues on bush much longer, fully as prolific, in some trials largely outyielding it.

CHAMPION BLACK. A new variety from England; pronounced the finest black Currant ever brought to notice. The bushes are very large and the flavor of the fruit excellent.

CHERRY. The largest of all red Currants; berries are sometimes more than half an inch in diameter; bunches short; plant very vigorous and productive when grown on good soils and well cultivated.

FAY'S PROLIFIC. Has been carefully cultivated for the past twelve years alongside of all the popular varieties, and proved by far the most prolific of all. Color rich red. As compared with the Cherry Currant, Fay's Prolific is equal in size, better flavored, with much less acid, and five times as prolific; also, from its peculiar stem, less expensive to pick. It is one of the few good things that will sustain all the claims made for it.

PERFECTION. A fine new currant of superior merit. Berry very large, larger than Fay's; clusters averaging longer, color a beautiful bright red; flavor rich, mild sub-acid. A great bearer, less acid and of better quality than any other large currant in cultivation. The Perfection was awarded the Barry Gold Medal of the, Western New York Horticultural Society. Also received highest awards at Pan-American and St. Louis Expositions.

WHITE GRAPE. Very large, yellowish white; sweet or very mild acid, of excellent quality and valuable for the table. The finest of the white sorts. Very productive.

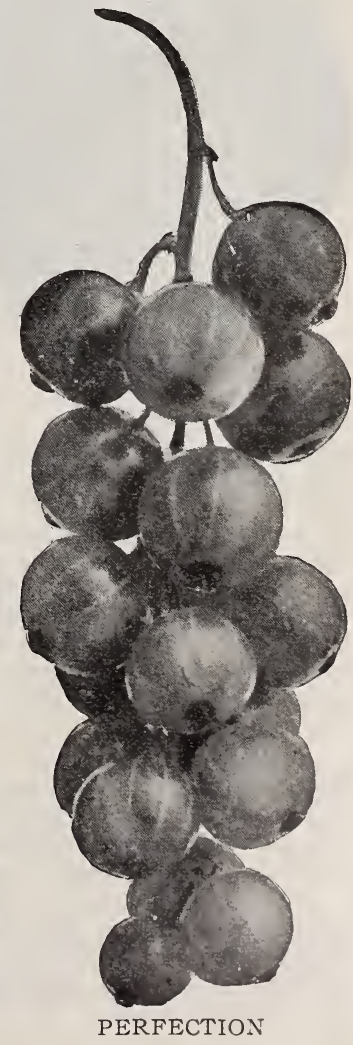




\section{G O O S E B E R R I E S}

The Gooseberry requires the same cultivation and treatment for worms as the currant. The worm attacks the Gooseberry before the currant bushes, and should be closely watched as soon as the growth gets a few inches long. Dust or sprinkle the leaves with hellebore as soon as the first worm is discovered, or about the 10th or 12th of May. These worms come three times during the season, and should be closely watched through the summer.

DOWNING. Fruit smooth, larger than Houghton, roundish, light-green with distinct veins; flesh rather soft, juicy and very good. The most valuable American variety.

PEARL. A very productive and perfectly healthy variety, quite free from mildew. Pearl is a favorite and hard to beat; bushes planted but one year are said to yield three quarts of berries. A robust, vigorous grower, with berries larger than Downing, and of excellent quality.

COLUMBUS. A new American seedling of English type; fruit large, greenish yellow, smooth, of high quality; bush strong, robust, has never shown a trace of mildew. Is believed to be the best American Gooseberry yet introduced.

JOSSELYN (Red Jacket). A new American variety, for which the introducer claims great productivenness, hardiness, excellence of quality and freedom from mildew, it having been tested seven years beside other sorts, all of which, except Red Jacket, were badly affected. Berry large and smooth.

INDUSTRY. A variety of foreign origin which, in most northern portions of the United States, does well, and, under favorable conditions, is exceptionally free from mildew

\section{S T R A W B E R R Y PLA N T S}

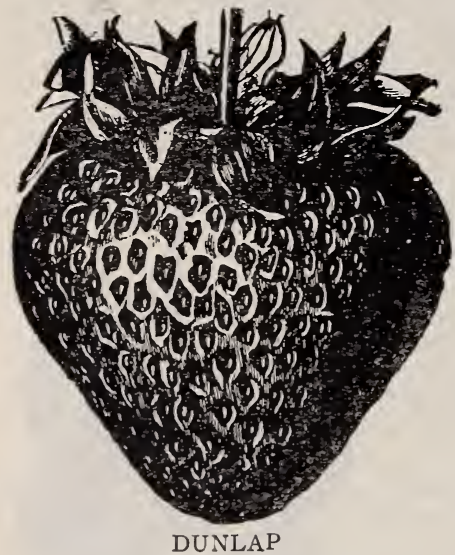

THE STRAWBERRY may be grown to perfection on any ground that will produce a crop of potatoes, corn, peas or other vegetables. Ground that has been used for fruit or vegetables is the best.

The ground should be prepared the same as for other crops; if not.already rich, make it so by manuring. Mark out the rows the desired width, and set plants 12 to 18 inches apart in the rows. If set 12 inches apart in rows 4 feet apart, an acre will require 10,890 plants, same as if set 16 inches, in rows 3 feet apart.

We give decided preference to April and May for planting Strawberries, and confine our transplanting and sales to those months, except pot grown plants which we offer after July 15th for summer and early fall planting. The earlier they are planted in the Spring the better. keeping the roots from being dried by the wind or sun. To produce large berries, the runners must be pinched off, thereby throwing the strength of the plant into the fruit.

Those varieties marked "Imp." are pistillate or imperfect flowering. These varieties are among the best in quality and productiveness, but they must be planted with the perfect flowering varieties so that the blossoms will mix and fertilize. Plant the pistillate varieties between the perfect flowering, having one row of the perfect to every two or three of the pistillate.

One who has never tried it will be astonished to find how large a crop of berries can be produced on a few square yards in the graden; often more than enough to supply a large family. It is not at all unusual to get two or three bushels from a plot of ground one rod square.

ABINGTON (Perfect). We fruited this last season for the first time and were greatly pleased with it, it is a great cropper. Take Abington and Sample and you have a whole team and a strong one. It is fully as productive as Sample and larger.

ARNONT (Perfect). Has large, heavy, thick, glossy foliage, resembling Glen Mary. Is free to make plants. The berries are bright red, solid, and good flavor. It is productive and a good shipper. Needs strong soil for its development.

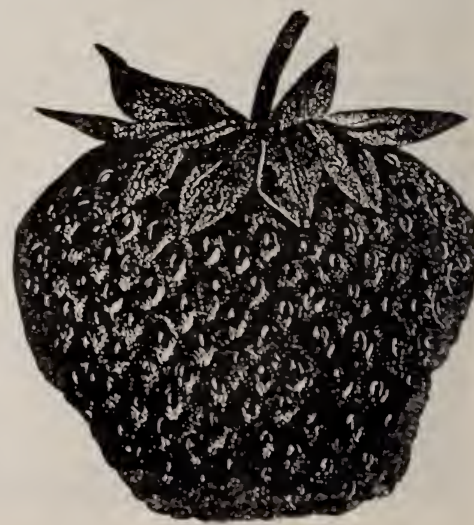

KANSAS 
BEVERLY (Perfect). A seedling of Old Miner's Prolific. Those who have fruited this berry speak in highest terms of it. It is a very handsome berry and sells well in market.

BISMARCK (Perfect). We have in Bismarck an extraordinary large berry, glossy, fine color, good shape and good quality, with vigorous plants, full of vitality. It ripens all over at once, having no green tips, and the berries are quite firm and an excellent shipper. Season medium early.

BRANDYWINE (Perfect). Season medium to late. One of the heaviest fruiters and a splendid shipper. Berries very large, deep red to center; stem short and stout, holds its great load of berries well up from the ground. One of the strongest pollenizers for pistillates of the season.

BUBACH (Imp.). One of the best varieties we have. In productiveness unsurpassed.

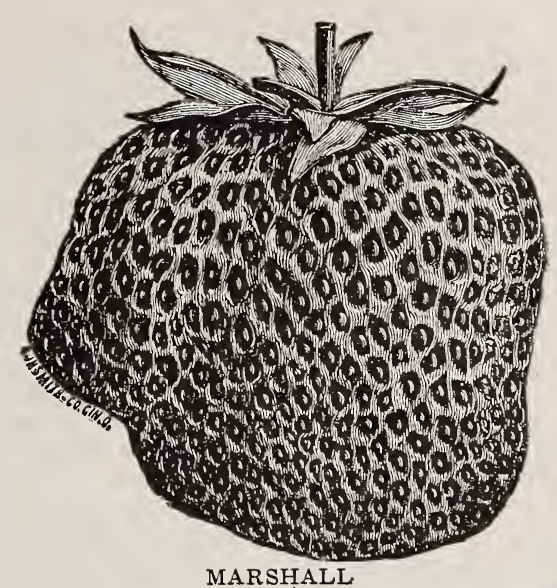
Noted for its uniform and large size. The plant is hardy and the leaves endure hot sun, as it is a very robust variety, and does not rust. Mid-season.

BUSTER (Imp). It is a cross of Bubach and Sharpless, of large size, bright red. $\mathrm{Mr}$ Allen of Maryland says: "This is a good reliable variety that I advise you to plant, it will please you from the time it starts to grow until you have harvested your crop."

CLIMAX (Perfect). This is an extremely popular variety, very productive, of medium large, rich, dark, glossy red berries of high quality, ripening early.

CLYDE (Perfect). One of the best of the early, large-fruited varieties, yielding abundantly, and is very profitable. The berries are bright in color, hold up well, being moderately firm, and owing to their quality, good size, earliness and fresh color, sell quickly and bring in good returns.

COMMONWEALTH (Perfect). This berry won first prize two years in succession at the Massachusetts Horticultural Society. It is very large, dark red solid flesh, and one of the latest varieties.

CORSICAN (Perfect). The introducer says it is the biggest berry, brightest in color, greatest yielder on earth, most vigorous foliage, resisting fungous, drought, weeds, and lack of cultivation, and-well, that's enough.

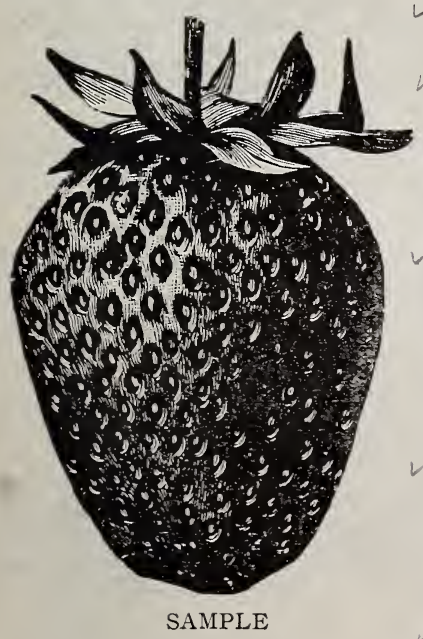

CRESCENT (Imp.). Very productive, bright red, medium-sized berry.

DIGHTON ROCK (Perfect). C. E. Carr of Massachusetts says, this is a fancy berry and a great cropper, and that if he were going to set out only one kind lof strawberry it would be Dighton Rock, and thinks $\$ 500$ to $\$ 1,000$ per acre could be made with it under high culture.

DUNLAP (Perfect). A very productive dark red conical berry of excellent quality, ripening medium early. If you want a variety that will give you good berries for your home, berries that will be in demand in your local market, berries good enough to send to your best friend, and a good variety for shipping, in any event don't overlook the Dunlap.

EXCELSIOR (Perfect). This is a valuable, early, perfect-blossoming strawberry. Large, fine color, vigorous plant, firm, productive and desirable for home use or for market. After repeated trials we do not hesitate to say that we know of no other early strawberry that is its equal. Successful on all soils.

GANDY (Perfect). This superb late variety is second to none as a fine, handsome, beautiful, firm, fine-flavored, late berry. The fruit always brings the highest market price. This is one of the most profitable berries to grow for a fancy "market or for home use, where quality is the first consideration. 
GLEN MARY (Perfect). A choice variety that will well repay extra care and culture, delighting the amateur; and one that is profitable, also, in a fancy market. The berries are large, bright glossy crimson, and so handsome as to bring the highest price; moderately firm and fine in flavor. The plant is vigorous and healthy, very productive, and the berries maintain their large size until the close of the season. Season medium to late.

HAVERLAND (Imp.). The smallest plants of the Haverland bear abundantly. The fruit is long and large, light red, very attractive, moderately firm; season early. A valuable berry for home use.

HUMMER (Perfect). These large vigorous plants load up with big, beautiful, luscious berries and are highly thought of by many.

JESSIE (Perfect). A highly colored berry of excellent quality, succeeding best in heavy and stiff soils of high fertility.

JOHNSON'S EARLY (Perfect). A good variety if grown in thin matted rows, but if allowed to set all the plants it will make, it will become so thickly matted in the row that it cannot mature a crop. The berries are medium size, deep red and excellent quality. One of the earliest.

KANSAS (Imp.). The plant is an extremely vigorous grower, and as free from disease or rust as any ever grown. Its fruit is a brilliant crimson, not only on the surface, but through and through. This feature, together with its very strong strawberry flavor, will make it, when it becomes better known, perhaps the most popular strawberry for canning ever yet produced. Time of ripening, late. It is very productive of fine medium to large berries that make a very handsome showing in the package, and always attract the best buyers, and the berry is firm enough to make a good commercial variety.

LADY GARRISON (Perfect). Fruit of large size, fine globular form, bright glossy red color and fine flavor, a strong rampant grower; begins to ripen early, and season extends through to the later ripening varieties.

MARSHALL (Perfect). The plant is large and strong; very prolific; 110 berries have been counted on a single plant. The fruit is handsome and attractive; very large, fourteen berries having been known to fill a quart box. Of perfect form; dark crimson when fully ripe, but covers all over a light crimson before ripe, and is thus valuable for market. Quality and flavor excellent.

MEAD (Perfect). This promising new variety originated in Massachusetts. The originator says: "It is a good thrifty grower, with healthy foliage, perfect blossom, and fruit as near perfection in shape and form as any I ever saw. Flesh reddish and solid, and to my taste one of the best in quality. It is a heavy cropper of good-sized berries, which hold their size well till close of season. It colors evenly, with no white tips, does well on all kinds of land, and will make a good showing on very light soil." It resembles the Clyde in shape; color glossy red and promises to rank with Sample as a producer and with Gandy as a shipper.

MINUTE MAN (Imp.). It is hard to decide which is best, this or Sample. It is a good grower, large, good color, and quality. A good market berry on light land.

MISS BOSTON (Imp.). This berry is recommended very highly by some of the Dighton, Mass., growers. Said to be as productive as Haverland and a better shipper.

NETTIE (Imp.). Out of 50 or 60 varieties we fruited last season this was the latest. It is very large and productive. In color-well, it makes us think of a freckled mulatto, but its size and lateness make it sell.

NEW YORK (Perfect). This variety is fast becoming a favorite. It is a cross of Bubach and Jessie. Mr. Kellogg says: "New York is a fancy berry for fancy trade. Very large, bright red, strong foliage, and heavy fruiter."

NICK OHMER (Perfect). Large, regular, dark, glossy red, firm and of excellent flavor; very vigorous and productive.

OOM PAUL (Perfect). Mr. Kevitt of New Jersey says this is the largest berry he ever fruited. The first season he fruited it he sold every box for 25 cents, one box selling for $\$ 10$, it had six berries in it, and also that it is a marvel of productiveness.

PARSON'S BEAUTY (Perfect). One of the most productive berries grown. Medium to large size, dark red, commencing to ripen early and continuing through mid-season. Plant of great vigor, with dark, rich green foliage. A grand market or family berry. Those not growing this splendid variety should give it a trial. Does its best on low, somewhat heavy land.

PRIDE OF CUMBERLAND (Perfect). An abundant bearer of very handsome bright glossy red berries. Has all the good points of the Gandy, better in quality, ripening about one week earlier than that popular variety. Will thrive on any soil, but best results are obtained on rich land; a long keeper and superb shipper. 
ROUGH RIDER (Perfect). Said to be of size and shape of Bubach and as productive as Sample; requires stróng, rich soil and good care, when it cannot be beaten.

SAMPLE (Imp.). This new berry originated in Massachusetts. It is of large size, quite firm, commences to ripen mid-season and continues till very late, keeping up a continual supply of large berries to the end. The foliage is large and healthy, blossom imperfect, fruit of good quality. It is truly a marvel of productiveness and a variety which will yield dollars to those who plant it.

SAUNDERS (Perfect). Large, deep glossy red, good pollenizer; yields good crops on light soils.

SHARPLESS (Perfect). A well-known and popular variety, producing large berries of mild, pleasant flavor. Berries are large, color bright crimson. Its large, handsome fruit and good quality have made it a favorite. Mid-season.

SOMERSET MAID (Imp.). Mr. Carr of Massachusetts says he recommends this as one of the very best fancy berries to set in his vicinity. Fruit very large, bright scarlet and firm, and bears immense crops on high or low land.

STEVENS LATE CHAMPION (Perfect). This is one of the most profitable and productive late berries we know of, and seems to do well in almost all soils and locations. Berries large in size, dark red, and firm.

SUCCESS (Perfect). This is the largest and best extra early berry we have ever fruited; would not be a good shipper, but for a nearby market can't be beaten for its season.

TENNESSEE PROLIFIC (Perfect). A large, handsome berry with healthy foliage and finely colored fruit. It is one of the best berries we know and one of the best pollenizers for pistillate sorts.

UNCLE JIM (Perfect). A moderate plant maker, but the plants are large and make good rows. Fruit is large, high quality, handsome, firm for so big a berry.

WARFIELD (Imp.). Medium size, dark red in color, splendid shipper. If the plants are not left too thick it is unsurpassed in productiveness.

WM. BELT (Perfect). Large size, bright, glossy red. In productiveness, size and quality, Wm. Belt will scale high.

\section{R A S P B E R R I E S \\ CARE AND CULTURE OF RASPBERRIES}

Any ground capable of raising good general crops is suitable for Raspberries, or they may be grown at a profit in young orchards. Red Raspberries, for field culture, should be planted in rows 7 feet apart and 2 feet apart in the rows; for garden culture, $4 \times 5$ feet. The canes should be cut back within a few inches of the ground immediately after planting. In pruning the bearing canes, cut back, on an average, half their length. Old

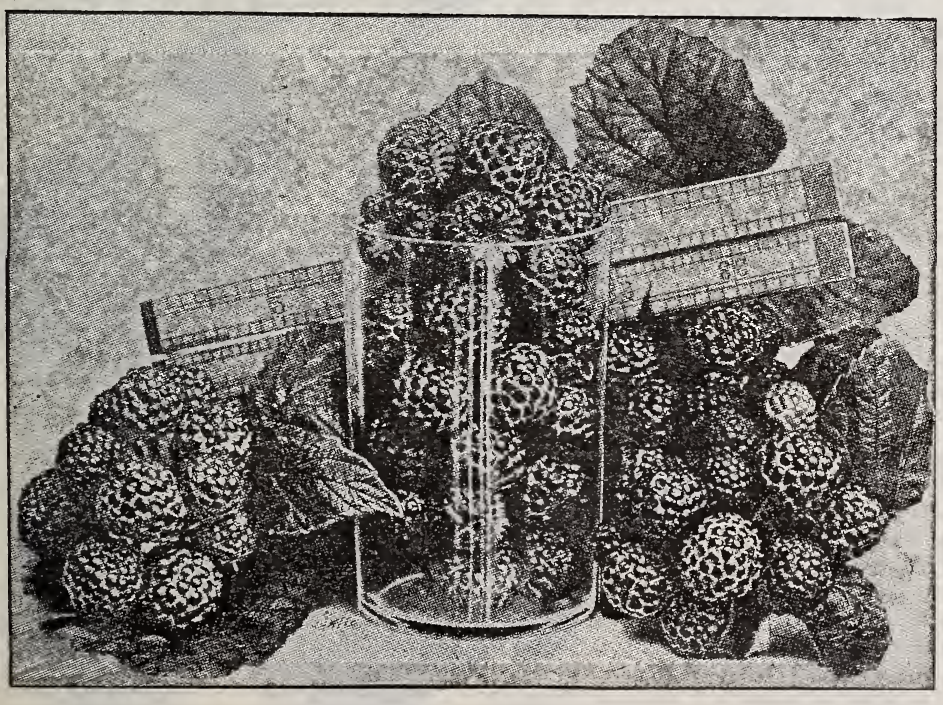
canes should be cut out after the freeze of winter. Blackcaps are raised similarly to the Red. varieties; they may be raised on lighter soil than the Red. In pruning the bearing canes, cut back about three feet.

\section{BLACKCAPS BLACK DIAMOND}

We have not fruited this berry, but it is said to be a very large berry, fully as large as Gregg and a week earlier and jet black; the plants are strong growers and ripen up the fruit quick. 
"It is certainly the finest black raspberry we ever had in our section."-B. J. Case, New York.

CONRATH. One of the very early varieties, but of the Gregg type, being large, firm and sweet. It is very productive and valuable for an early variety.

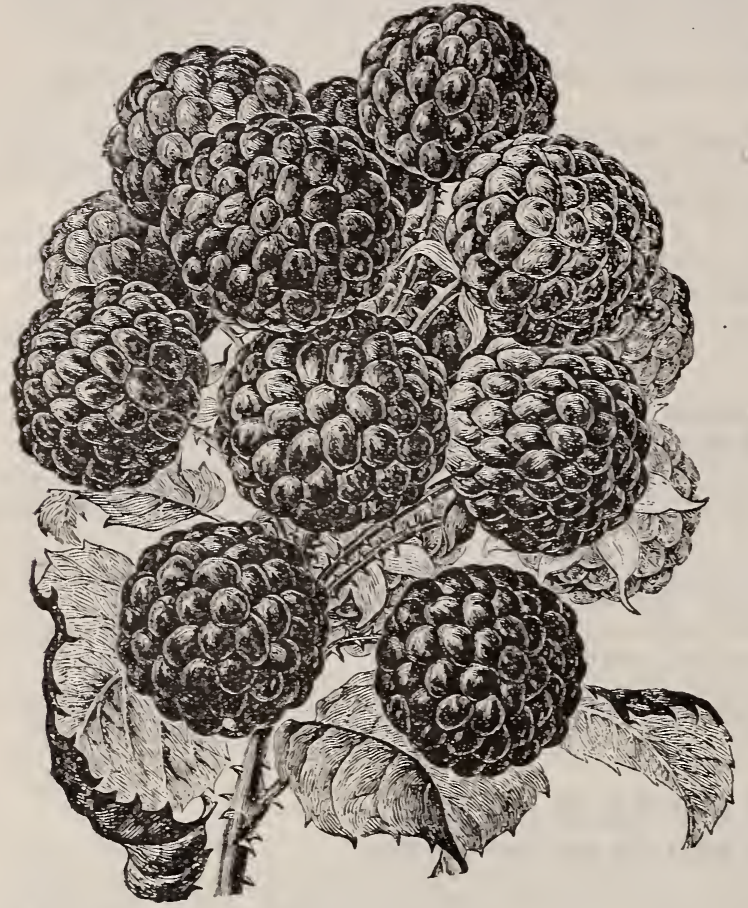

GREGG. An old variety, the standard of size and productiveness by which other varieties are compared. Its late ripening, large size, make this variety a favorite.

CUMBERLAND. The fruit is simply enormous; the berries measure nearly an inch in diameter; but, in spite of this, are unusually firm and thus well adapted for standing long shipments. In time of ripening it precedes Gregg. The bush is extremely vigorous and remarkably free from disease.

KANSAS. Strong, vigorous grower, standing extremes of drought and cold, and bearing immense crops. Berries size of Gregg, of better color; jet black, and almost free from.bloom; firm, of best quality; early.

MUNGER. The fruit of Munger is black, and very large and firm; splendid for canning, and brings a larger price in market than other sorts.

NEMAHA. The Nemaha is an excellent, large, black, good"quality, late variety; in Wisconsin large fields of the Nemaha are seen. It originated in that state, and therefore it is no wonder it is hardy. One

grower in Wisconsin who has ten acres of this famous Raspberry, says: "Nemaha yields 150 bushels to the acre." Before this variety was known, Gregg was the only extra large leading black cap. Nemaha excels it in hardiness of bush and in quality of fruit.

PLUM FARMER. Mr. Farmer, the introducer, says it is the very largest black cap he has ever grown or seen, more productive than Kansas or others that he has tested. It is very firm and of best quality. Our stock was obtained from Mr. Farmer.

\section{RED AND YELLOW VARITIES}

PHOENIX. This is a very superior extra early red variety; is phenomenally hardy and needs no shortening in. Even the end buds carry out their full quota of fruit. It thrives on land that is wet or dry, poor or rich; but fertilize highly if you want the best

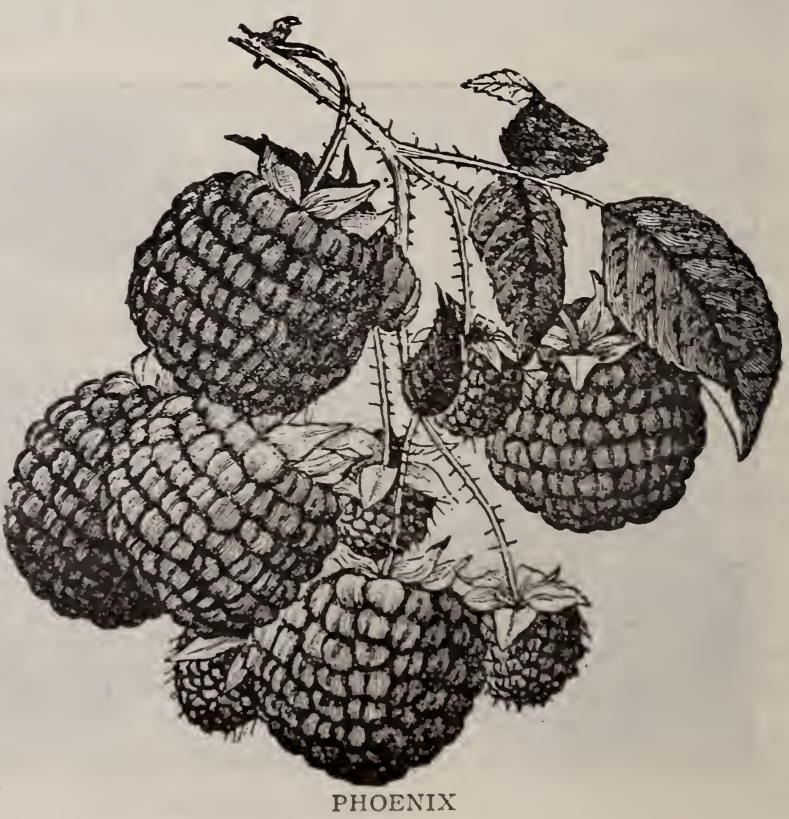


results. The Phœnix is early, it is late, it is a good looker, a good cropper, a good seller and a good canner. It is hardiest of the hardy. It thrives on all soils and is very free from disease.

COLUMBIAN. This variety will, under the right conditions, produce more fruit than any other Raspberry in cultivation. It is a rampant grower. The originator trained a bush to grow 13 feet high, which produced one bushel of fruit. L. J. Farmer of New York says he has picked at the rate of 5,000 bushels to the acre at one picking. The fruit is large, purple in color, and splendid for canning.

CUTHBERT. Very large and handsome, of good quality; ripens a little late and continues a long time in fruit; hardy and productive.

HERBERT. This new raspberry originated near Ottawa, Canada. It has undergone a thorough test beside the older varieties, as well as later introductions, and outclassed them all. It is very hardy, has stood 30 degrees below zero at its home in Canada without injuring a tip. It is a heavy bearer of extra large, firm, fine-colored fruit that holds its size well to end of season. From the Horticulturist at the Experimental Station at Geneva, N. Y.:

"In reply to your request of August 6th, in regard to report on the Herbert Raspberry, will say that this variety has made a very good showing this year. The winter injury on two 27 -foot rows was 5 and 10 per cent., respectively, the yield averaging 368 ounces. The injury to one row of Cuthberts of the same length was 25 per cent., the yield

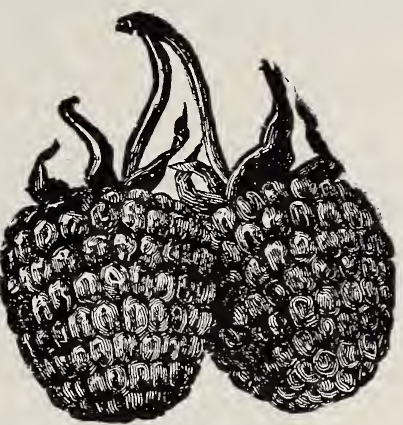

CUTHBERT being 226 ounces. The growth of the canes of HERBERT is not so tall on our soil as that of Cuthbert, but we find that the berries average larger and are nearly as attractive as Cuthbert in general appearance. It is certainly a variety worthy of trial, and I have no hesitation in recommending it for this purpose." Beware of spurious plants being offered at low prices, ours are the genuine.

GOLDEN QUEEN. A yellow variety of great merit; similar in habit, quality and size to Cuthbert. Should be in every home garden.

\section{B L A C K B E R R I E S}

In garden culture, Blackberries should be planted in rows 6 feet apart, and the plants about 4 feet apart in the rows; in field culture plant in rows 8 feet apart, and the plants 3 feet apart in the rows. The tops should not be cut off till about $31 / 2$ feet high, and should not be so closely pruned in the spring; otherwise their culture should be the same as for Raspberries.

ELDORADO. Eldorado now stands high above any other Blackberry, and all agree that it has never winter-killed or failed to produce a full crop of the finest fruit. While it is of superior flavor and very large, the vines will also stand the winters of the far northwest without injury. The yield is enormous, the fruit being jet black, in large clusters, ripening well together. Very sweet and without core.

RATHBUN. Fruit is of enormous size, far surpassing that of any other variety, 45 berries filling a quart box, single specimens measure $1 \frac{3}{4}$ inches in length, and the whole crop is very uniform. Fruit is quite firm, sweet, with no core, and ships well. Plant is not very hardy; a strong grower, with branches curving over, touching the ground and propagating themselves like a blackcap raspberry.

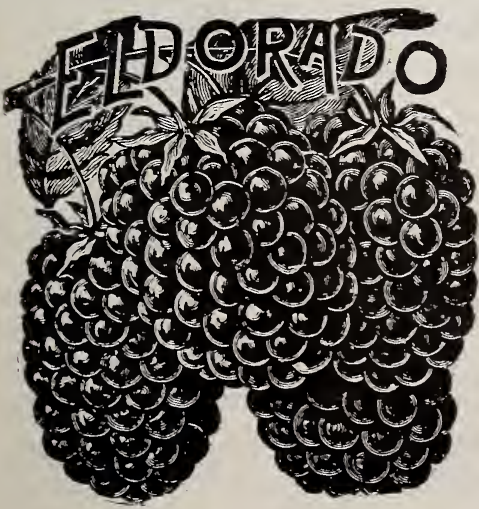

MINNEWASKI. Vigorous, enormously productive of extra large fine fruit that ripens extremely early, has been a great market variety for the Hudson River section.

SNYDER. An old, well-known variety. Very hardy; will endure severe cold without injury. Good quality for market purposes. Medium size; no sour, hard core; few thorns.

THE WARD BLACKBERRY. This new Blackberry was found growing in a fence row, alongside of a patch of Wilson. The plant is remarkably vigorous and healthy, free from rust, well branched yet making strong, erect fruiting canes enabling them to carry and develop their immense loads of fruit. Foliage dark green, healthy and free from rust, blossom perfect, never showing a sign of doubling. Fruit jet black in color, very firm, tender and melting, without core and of the highest quality. 
MERSEREAU. " This variety was originated in Western New York, where the mercury falls below zero each winter. It has been well tested and found to be perfectly hardy. It makes very large canes, is very productive, of large size, delicious quality, hangs on the bushes till fully ripe, does not turn red in the baskets, has an unusually long season.

Prof. L. H. Bailey says: "It is one of the most promising varieties I know."

LUCRETIA DEWBERRY: The best of the Blackberry family and decidedly the most productive. The berries are far larger and incomparably better than any blackberry, and of unequalled excellence; sweet and luscious throughout. Should be covered like strawberries in winter.

\section{A S P A R A G U S}

Asparagus usually sells at a good price, and, being ready for market in April and May, the income derived from it is especially appreciated at that time of the year. It is usually planted on light soil to have it early, though it can be easily grown on all good garden soils. The sprouts are not usually cut until the second or third year after planting, except.to mow down the canes in the fall. The roots will give good crops for from 15 to 20 years, selling at $\$ 100$ to $\$ 200$ per acre. Plant the roots in the spring or fall, from 4 to 6 inches deep, covering with only 3 inches of soil at first, and filling in the trenches as the plants grow.

CONOVER'S COLOSSAL. Very large; makes rapid growth; planted mostly by marketgardeners; very productive.

PALMETTO. Of southern origin; a variety of excellent quality; early, very large, very prolific; all who have used it pronounce it ahead of any other.

\section{R H U B A R B}

RHUBARB, MYATT'S LINNAEUS. Those who have never grown this variety, which is of superior quality, will hardly recognize the old "Pie Plant." It is an early, tender variety, not in the least tough or stringy, with a mild, sub-acid flavor.

\section{OR N A M N T A L DEPART MENT}

Although still greatly neglected in many places, the people of all sections in city, town and country are awakening to the fact that the town lot and farm yard, as well as the country villa, is of greater value when attractively planted with a judicious selection of ornamentals; that an investment of hardy trees, shrubs, roses and plants used in beautifying the home grounds and street, returns a greater interest in actual cash value than is possible with an outlay of similar amount in almost any other way, to say nothing. of the added beauty, the increased comfort and health of the occupants.

Hardy trees and shrubs can now be obtained at moderate cost, that will stand the extremes of temperature and soil of nearly all sections; judicious selection will obtain deciduous and evergreen trees that make beautiful specimens the year through, deciduous trees and shrubs giving constant succession of bloom through the season, while the purple, variegated leaved and weeping forms are always ready for variety and contrast.

For more complete list and description, write for our special ornamental catalogue.

\section{DESIRABLE ORNAMENTAL TREES TO PLANT}

\section{A LIST OF TREES RECOMMENDED FOR VARIOUS PURPOSES}

For more complete list and description, write for our ornamental catalogue.

FOR STREETS, ROADS AND WIDE AVENUES. American Elm, Sugar, Sycamore and Silver Maples, Carolina Poplar, Pin Oak.

FOR DRIVEWAYS THROUGH LAWNS AND PARKS. Norway Maple, Salisburia or Gingko, Tulip Tree, Magnolia Acuminata, Catalpa Speciosa, to which we add American and European Lindens.

SINGLE SPECIMENS OF LARGE GROWTH. English and Rivers' Beech, Birches, particularly Cut-leaf Weeping; English and Purple-Leaf Elms; American, European and WhiteLeaf Lindens; Norway, Purple Norway, Sycamore and Cut-Leaf Maples; Horse Chestnuts; Austrian and Scotch Pines; Norway and Colorado Spruces.

SINGLE SPECIMENS OF MEDIUM GROWTH. Imperial Cut-Leaf Alder, Fern-Leaf and Weeping Beech, Catalpa Bungei, Purple Birch, Horse Chestnuts, Laburnum, Chinese Magnolias, Oak-Leaf Mountain Ash, Prunus Pissardi, Flowering Thorns, Hemlocks, White Pines, Siberian Arbor Vitaes, etc. 
STRONG GROWING TREES OF PYRAMIDAL HABIT. Lombardy and Bolleana Poplars. TREES THAT THRIVE IN MOIST LOCATIONS. American Elm, American Linden, Ash, Catalpas, Poplars and Willows.

TREES THAT THRIVE ON DRY KNOLLS OF POOR SOIL. Silver-Leaf Maples and Poplars.

BEST TREES FOR WIND BREAKS. Norway Spruce (evergreen), Carolina Poplars and Silver Maples.

FLOWERING TREES. Magnolias, white and purple; Judas Trees, Peach, pink and white; Laburnum, yellow; Fringe Tree, white and purple; Lindens, Horse Chestnut, red and white; Cherry, white; Catalpa, Thorns, pink, scarlet, red, white.

CUT-LEAVED TREES. Imperial Cut-Leaved Alder, Fern-Leaved Beech, Cut-Leaved Birch, Wier's Cut-Leaved Maple.

PURPLE AND SCARLET-LEAVED TREES. Purple-Leaved Beech, Purple-Leaved Birch, Purple-Leaved Elm, Prunus Pissardi, Purple Norway and Sycamore Maples, Japan Maples.

WEEPING OR PENDULOUS TREES. Ash, Beech, Birch, (Cut-Leaved and Young's), Cherry (Dwarf and Japanese), Crab, Cypress, Dogwood, Elm (Camperdown), Linden (Whiteleaved), Maple (Wier's), Mountain Ash (European), Mulberry (Teas'), Willow (Babylonica, Kilmarnock, and New American).

HEDGING. California Privet, Barberry Thunbergii, American Arbor Vitae, Hemlock and Norway Spruce, Honey Locust.

\section{DECIDUOUS TREES}

EUROPEAN BEECH. A large and beautiful lawn tree resembling American Beech, but more compact in habit.

WEEPING BEECH. A strong growing variety with fairly straight, upright trunk from which spread straggling and crooked branches.

PURPLE OR COPPER BEECH. Foliage red, purple in early summer.

RIVER'S PURPLE BEECH. A variety with large, smooth, very dark leaves. The best purple lawn tree known.

WEEPING PURPLE BEECH. A variety with large, purple leaves and drooping branches. $A$ very rare and beautiful tree.

FERN-LEAVED BEECH. Has finely divided fern-like foliage and well formed growth. A very popular ornamental tree.

EUROPEAN WHITE WEEPING BIRCH. A graceful tree, with silvery bark and slender branches. Quite erect when young, but after four or five years' growth assumes an elegant drooping habit, rendering the tree very effective in landscapes.

PYRAMIDAL BIRCH. Of elegant pyramidal habit, like the Lombardy Poplar. Bark silvery white. Very distinct and ornamental.

PURPLE-LEAVED BIRCH. A variety possessing the vigorous habit of the Birches, and having purple foliage.

CUT-LEAVED WEEPING BIRCH. Beyond question one of the most popular of all weeping or pendulous trees. Its tall, slender, yet vigorous growth, graceful drooping branches, silvery-white bark, and delicately cut foliage, present a combination of attractive characteristics rarely met with in a single tree.

PAPER OR CANOE BIRCH. Native of America; forms a large tree; bark brilliant white, leaves large and handsome.

CATALPA SPECIOSA. An exceedingly rapid grower. Heart-shaped leaves, and clusters of white and purplish flowers in midsummer; very attractive.

CRAB, DOUBLE-FLOWERING AMERICAN. New. A sturdy grower, hardy and of medium size; blooms while very young. The flowers resemble delicate pink roses. When in bloom looks like a mammoth rose bush.

CHERRY, JAPANESE FLOWERING. One of the most beautiful flowering trees of the far east. Remarkable for the profuseness of its flowers.

HORSE CHESTNUT, RED. Beautiful, slow growing tree, with rosy red flowers.

HORSE CHESTNUT, WHITE. Beautiful creamy white, fragrant flowers. A fine, symmetrical tree, with large, rich foliage.

LINDEN. The American and European Lindens are our best large-leaved shade trees. Specially adapted to lawn planting. Foliage is dense, and when in bloom their fragrance is delightful. The Lindens are all beautiful and merit more notice than they receive. They possess many valuable qualities. 
MAGNOLIA. A class of valuable and beautiful trees, because of their fine foliage, luxuriant appearance and fragrant flowers. They are the best lawn trees in our collection.

MAGNOLIA, ACUMINATA. (Cucumber Tree). A magnificent native tree, with large pointed leaves six to nine inches long; blossoms green and yellow, four to six inches in diameter: fruit resembles a green cucumber.

MAGNOLIA, TRIPETALA. UMBRELLA TREE. A tree with stout irregular branches, leaves ten to twenty inches long and six to eight wide. Flowers creamy white, eight or ten inches across in spring.

MAGNOLIA, CHINESE VARIETIES. These are the dwarf growing, large flowering varieties, of which the best are Speciosa and Soulangeana, white with red-purple centres, and Conspicua, pure white.

MAPLE, NORWAY. Round, spreading head; leaves large, thin, green on both sides, dark and shining.

MAPLE, SUGAR. For most purposes the most desirable shade tree in cultivation.

MAPLE, SILVER. For producing a quick shade, and especially for street planting, there are few trees superior.

MAPLE, WIER'S CUT LEAF. Graceful, imposing, and of extremely rapid growth, with foliage exquisitely cut.

MAPLE, SCHWEDLERS. Foliage of this variety is of a bright crimson in early spring.

MAPLE, JAPANESE. Handsome small trees or shrubs, on account of the varied shades of red, green and gold, and the wonderful outline of their leaves. .No garden or lawn is complete without them.

MOUNTAIN ASH, AMERICAN. Erect-growing, producing white flowers early in spring, followed by clusters of bright scarlet berries, which remain on the tree through the winter.

MOUNTAIN ASH, OAK-LEAVED. Compact, pyramidal head and dark lobed leaves, downy underneath. Flowers and berries like the preceding.

PALUSTRIS OR PIN OAK. A tall, upright growing variety when young, but with age the branches droop. Foliage bright and glossy. One of the best oaks for street planting, and becoming very popular.

PLUM, PURPLE-LeAved. (Prunus Pissardi.) Black bark and dark purple leaves, remaining very constant in color till late in the fall. Red fruit, which is said to be good.

POPLAR, CAROLINA. Desirable where quick shade is wanted, as it is one of the most rapid growing trees, and will thrive where most other sorts will fail.

POPLAR, LOMBARDY. A well-known, tall, erect-growing tree of rapid growth and spirelike outline; very essential in landscape gardening to give variety of form, and destroy the appearance of sameness produced by other trees.

PEACH, JAPANESE FLOWERING. Double flowers in pink, red, and in white.

PEACH, WEEPING FLOWERING. Very graceful, double white flowers.

STUARTIA PSEUDO CAMELLIA. Hardy, deciduous tree of good shape, growing to the height of twenty to thirty feet, producing single, white flowers resembling Camellias. From Japan.

STYRAX JAPONICA. Hardy tree growing to the height of ten to fifteen feet, with beautiful white flowers coming out in clusters like cherry flowers.

STYRAX OBASSIA. This hardy tree attains a height of twenty to thirty feet. Showy, large leaves with long white flower spikes, very sweet scented.

THORN, DOUBLE ROSE. Double rose-colored, fragrant flowers, with white tips.

THORN, DOUBLE WHITE. Small, double white flowers of great beauty. Makes a fine contrast when planted with the Scarlet.

THORN, SCARLET. Flowers large and double, bright scarlet.

TULIP TREE. Among the largest and handsomest of our native trees, forming broad spreading specimens, and one of the best for any situation where it has room to grow. Bark smooth, leaves glossy and fiddle shaped; flowers resemble tulips and appear in June.

Nursery stock arrived and am much pleased with it. Enclosed find check. 


\section{E VERGRE E T R E E S}

The advantages resulting from the general planting of Evergreens are many, and no grounds are complete without them. They retain their beauty through the summer heat and winter cold. Property is increased in value if its buildings are protected from winter storms by belts or large clumps of Evergreens, and a garden sheltered by tall evergreen hedges will produce vegetables from one to two weeks earlier than an open field.

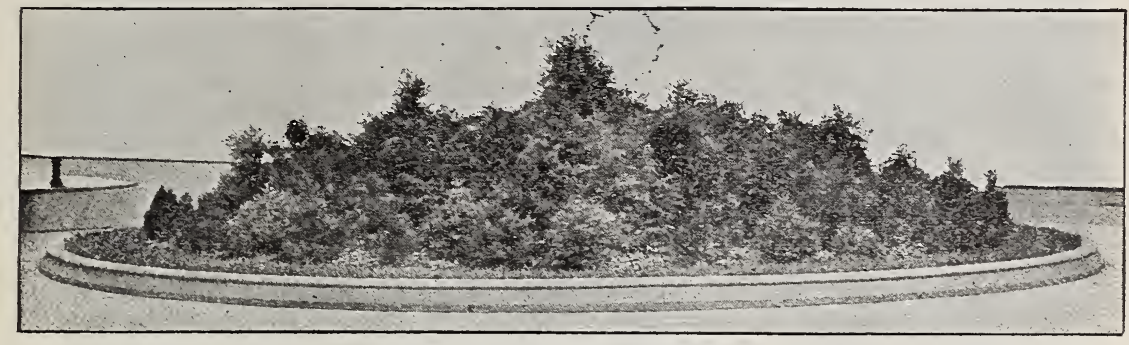

A Bed of Young Evergreens

The sap of most Evergreen trees being of a resinous nature is not so active in early spring as that of deciduous trees, and, as a rule, all Evergreens and Coniferous trees succeed better planted later in spring and earlier in autumn than deciduous trees. The latter part of April, or during May, and the latter part of summer, say in August, are the best times, in ordinary seasons, for transplanting in this latitude. August planting is not recommended, however, unless the season is favorable.

In handling and planting Evergreens never allow the roots to become dry for an instant. Their roots being resinous, when once dry water has no power to restore them. Dip the roots in "grout" or very thin mud, and plant quickly. Cover the roots with fresh soil, and with a heavy piece of wood beat the earth solid over them, fill up, pound again, and finish by bringing fresh loose soil about the tree with a hoe. If trees are planted when the ground is very wet, the pounding must be omitted until it is in working order to prevent baking. Planted in this way, and thoroughly cultivated with plow and hoe every week, Evergreens seldom fail to give abundant satisfaction. Give a heavy mulch. July 1 , and they are all right for the season.

ARBOR VITAE. (American.) One of the finest evergreens for single planting or hedges.

GLOBE. Dense and dwarf, forming a round ball without any training.

SIBERIAN. Similar to American, but retains its green color better.

HOVEY'S GOLDEN. Dwarf, dense, little evergreen with golden tinted foliage.

PYRAMIDAL. Very dense and pyramidal tree, the narrowest and most columnar of the arbor vitaes.

JAPANESE ARBOR VITAE. A dwarf compact form with bright green foliage.

JAPANESE GOLDEN ARBOR VITAE. A dwarf, dense growing shrub with golden yellow foliage.

BALSAM FIR. A very erect, regular, pyramidal tree, with dark green sombre foliage. Grows rapidly and is very hardy.

PINE, WHITE. Foliage white silvery green. Well known tree.

SCOTCH. Robust spreading tree with stout, erect shoots.

UMBRELLA PINE. A quite hardy, odd, Japanese tree of pyramidal character, grows slowly to large size. Each branch and shoot terminated by a whorl of umbrella-like tufts of needles.

RETINOSPORA, FILIFERA. Elegant formed tree with slender drooping branches.

PLUMOSA. Graceful habit with delicate glaucous foliage.

PLUMOSA AUREA. Foliage tipped with golden yellow.

SPRUCE, WHITE. A native medium sized tree of pyramidal form.

NORWAY. Similar to above, but more rapid grower, and coarser foliage.

SPRUCE, COLORADO BLUE. This magnificent tree is a native of the Rocky Mountains, and very hardy. It is of fine compact habit and of very symmetrical growth. The rich blue of its foliage makes a marked contrast to the green of other trees.

SPRUCE, KOSTER'S BLUE. Unquestionably the most beautiful of the spruces for garden or lawn. It is grafted from the bluest strain that can be found, the famous Koster variety.

HEMLOCK. A graceful and beautiful tree, with drooping branches, and delicate dark foliage. 


\section{DECIDUOUS SHRUBS}

These are much smaller than trees, and occupy much less space. They are very valuable planted as single specimens in the door yard, or in groups or masses, and a little planning in setting the kinds in the group will readily bring out the greatest individual beauty of the different kinds.

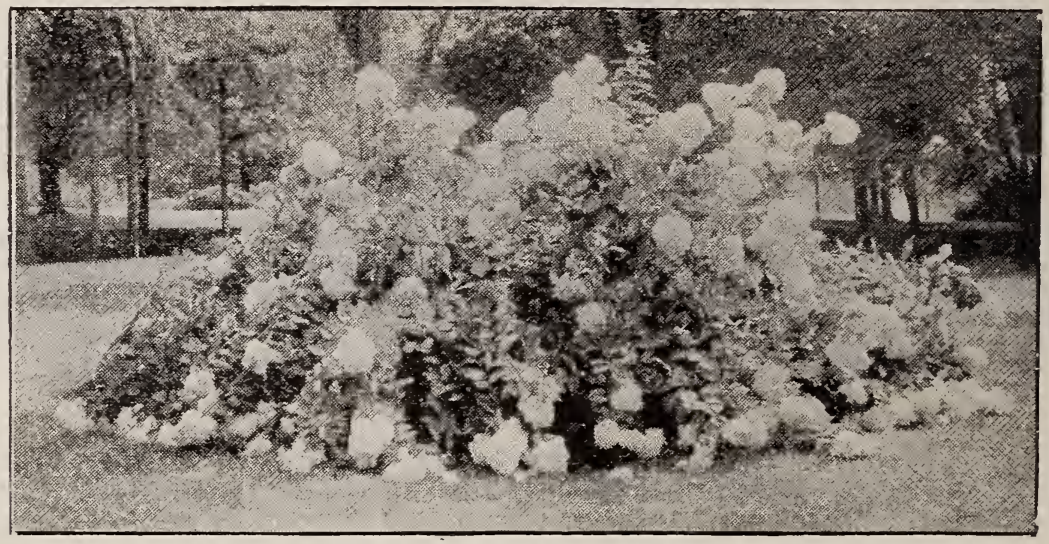

Hydrangea Paniculata Grandiflora.

.Hardy shrubs like the Weigelas, Deutzias, Spireas, Hydrangeas, etc., when planted in masses produce a magnificent effect. What grand masses of bloom can be had throughout the season by proper use of the various families. Then the purple and variegatedleaved trees and shrubs may also be planted in such a manner as to afford a rich and striking contrast. Highly effective groups can be formed of trees and shrubs possessing brightcolored bark in winter.

Deciduous trees, shrubs and vines can be planted either in Spring or Fall. By the proper use of the pruning knife or shears, the plants may be kept in handsome shape and proper size.

The best time for pruning all shrubs is when they have done flowering.

While our energies have been largely devoted to growing fruit stock we are increasing yearly our ornamental stock and are prepared to meet the increasing demand in this line. We have much land well suited for the propagation of ornamental stock which we are utilizing and all those who are thinking of beautifying their home grounds will do well to correspond with us, submit their lists or let us advise and we can quote special terms on large orders.

AZALEA (Mollis). Few classes of plants give a greater range of colors. These are especially attractive when planted in groups. Flowers appear in great profusion before the leaves in Spring.

A. SPINOSA. HERCULES CLUB. A native plant, valuable for producing tropical effects.

ALMOND, DOUBLE PINK. Small, rose-like flowers in May, before leaves appear.

ALMOND, DOUBLE WHITE. Similar to the pink, but flowers are pure white.

ALTHEA in variety, blooming in August and September. Double and single red, white, purple and combinations of these colors, also with variegated foliage.

BARBERRY PERPUREA. Purple foliage.

BARBERRY THUNBERGII. Beautiful foliage and berries in autumn.

B. VULGARIS. EUROPEAN BARBERRY. A handsome deciduous shrub, with yellow flowers in terminal drooping racemes in May or June, followed with orange scarlet fruit.

CALYCANTHUS FLORIDUS. Fragrant, chocolate colored flowers in August.

DOGWOOD. Red branched. White flowers in June.

DEUTZIA CRENATA. Pink flowers in June.

DEUTZIA, PRIDE OF ROCHESTER. White flowers in June.

DEUTZIA GRACILIS. Dwarf shrub with white flowers in June.

ELEAGNUS LONGIPES. Cherry-like edible berries in July.

ELDER, GOLDEN. Yellow foliage.

FORSYTHIA in variety. Yellow flowers early in spring.

FRINGE, PURPLE OR SMOKE TREE. Has curious bloom resembling smoke.

FRINGE. WHITE. White flowers in May and June.

HONEYSUCKLE, RED TARTARIAN. Upright shrub with red flowers in June.

HONEYSUCKLE, WHITE TARTARIAN. Same as above but with white flowers in June. 
HYDRANGEA PANICULATA GRANDIFLORA. Immense white flowers changing to pink. August and September.

HYDRANGEA, "HILLS OF SNOW". A new hardy variety, large snow-white blossoms, very prolific bloomer.

HYDRANGEA HORTENSIS VAR. AJISAI. New Hydrangea imported by us from Japan. Has indigo blue, starlike flowers. A favorite of the Newport gardens.

JAPAN QUINCE. Scarlet flowers early in spring.

KERRIA JAPONICA. (Japan Corchorus). A slender, green-branched shrub, 5 or 6 feet high, with globular, yellow flowers from July to October.

LILAC, PERSIAN. Bluish purple flowers. WHITE PERSIAN. White flowers.

CHAS. X. Reddish purple flowers.

MARIE LE GRAY. Best white flowering.

PLUM, Double Flowering. Double pink flowers in May.

PLUM (Prunus Pissardii). Purple foliage.

PEONIA. Tree. LOW shrub with flowers of gorgeous colors.

RHODODENDRONS. Magnificent flowering evergreen shrubs. Choice named varieties as follows:

A. Lincoln, crimson; Anna Parsons, soft red; Betsy Parson, reddish purple; Delicatissima, white and blush; Everestianum, rose; Gen. Grant, bright red; Parson's Gloriosa, soft rose; Parson's Grandiflora, rose; Purpureum Elegans, purple; President Lincoln, soft rose.

SPIREA BILLARDII. Spikes of rosy pink flowers from June through the summer.

ANTONY WATERER. Broad beads of deep pink flowers.

AUREA. Golden foliage, small white flowers.

PRUNIFOLIA. Double white flowers in bunches.

REEVSII. Beautiful clusters of white flowers.

THUNBERGII. Single white flowers in bunches; very graceful.

VAN HOUTTE. Finest of the Spireas. White flowers.

SNOWBALL, JAPANESE. Deep rich green foliage with globular heads of pure white sterile flowers.

SNOWBALL, GUELDER ROSE. Globular clusters of pure white sterile flowers.

S. RACEMOSUS. (Snowberry). A well known shrub, with small pink flowers, and large white berries that hang on the plant through part of the winter.

S. VULGARIS. (Red-fruited or Indian Currant). A shrub of very pretty habit. Foliage, flowers and fruit small; fruit purple; hangs all winter.

SYRINGA OR MOCK ORANGE. (Coronarius). Pure white highly scented flowers.

SYRINGA AUREA. Golden yellow foliage.

WIEGELA CANDIDA. Pure white flowers in June.

ROSEA. Pink flowers in June.

AMABILIS. Robust grower; pink flowers.

EVA RATHKE. Brilliant crimson flowers.

VARIEGATED. White flowers, silvery variegated foliage.

TAMARIX. These are very beautiful shrubs, with small leaves, somewhat like those of the Juniper, and delicate small flowers in spikes. They are invaluable for planting by the seaside, where scarcely anything else will grow.

AFRICANA. Handsome foliage, upright habit; flowers in May.

ODESSANA. July to September. Of lower growth. Pink flowers.

GALLICA. May to July. Lighter green foliage, and later in flower than variety Africana.

\section{CLIMBING AND TRAILING SHRUBS}

AMPELOPSIS VEITCHII, BOSTON IVY. For covering walls or the ornamentation of brick and stone structures, no plant is so useful.

BIRTHWORTH-DUTCHMAN'S PIPE. A native species, of climbing habit and rapid growth,

with magnificent light green foliage, ten or twelve inches in diameter and curious pipe

CLEMATIS PANICULATA. Vine with fragrant white flowers.

CLEMATIS HYBRIDS. Vines with large flowers, purple, white, blue and red.

HONEYSUCKLE, HALL'S JAPAN. Vine with fragrant white flowers.

HONEYSUCKLE, JAPAN GOLD VEINED. Vine with yellow variegated foliage.

HYDRANGEA SCANDENS. Another importation by us from Japan. Grows forty to fifty feet, covering walls, old trees, etc. like Ampelopsis Veitchii. The white flowers appear in great abundance and present a beautiful sight.

KUDZU VINE. A hardy and vigorous vine, frequently producing stems forty to sixty feet long in a single season. A veritable Jack-and-the-bean-stalk.

VIRGINIA CREEPER. One of the finest vines for covering walls, verandas, or trunks of t. trees, affords shade quickly. 
WISTARIA: Chinese Purple. Hardy climber with racemes of pale purple flowers.

CHINESE WHITE. Differing from above only in color, being pure white.

WISTERIA MULTIJUGA. White and purple. This bears racemes of flowers two to three feet in length.

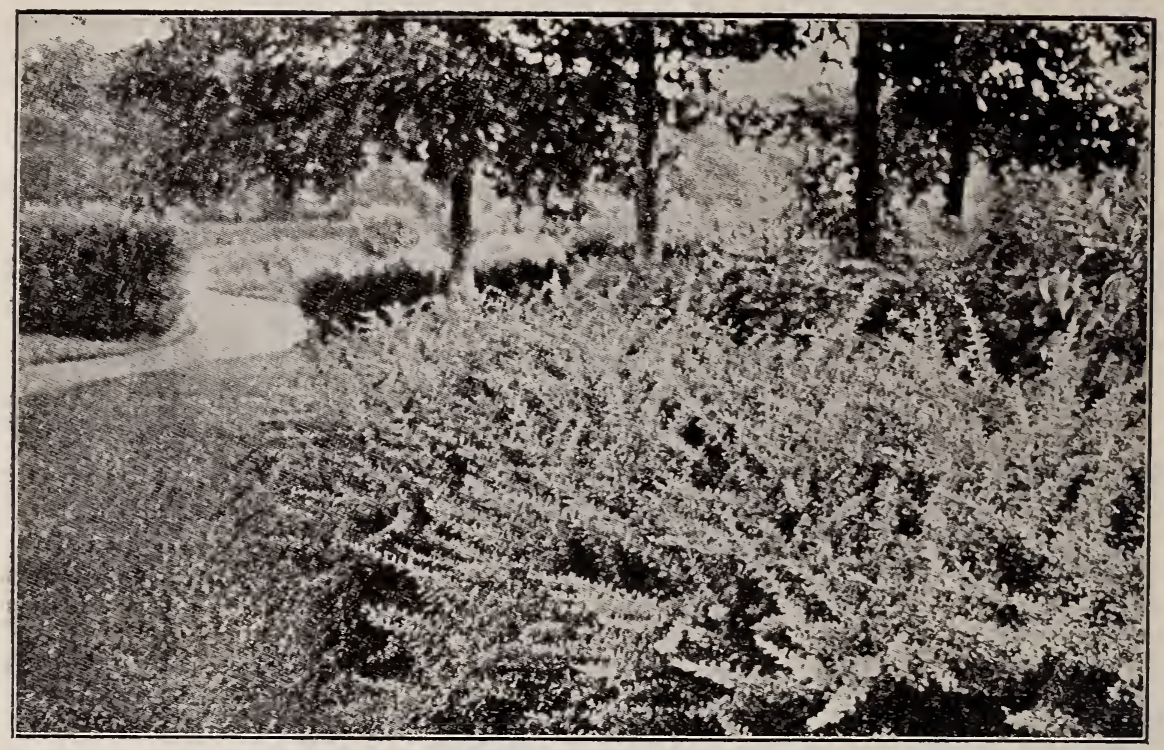

BERBERRY THUNBERGII

We have growing in our nurseries a large stock of this beatiful, graceful plant very desirable for hedges or for grouping. The crimson berries remain on throughout the winter giving a bright coloring to the winter landscape.

\section{HEDGE PLANTS}

Hedges are valuable as a defence against animals, as windbreaks to protect orchards, gardens or farms unduly exposed, and as ornamental fences or screens to mark the boundaries of a lawn or cemetary lot.

The usefulness of suitable hedges for both ornament and defense is now everywhere appreciated. To secure a good hedge it is necessary to plant well. Dig a wide, deep trench and work the soil thoroughly into the roots. Stamp the ground firmly so that each plant will be set solidly as a post, then mulch heavily with loose strawy manure for a distance of from one to two feet on each side, according to the size of the plants. This precaution is especially necessary with Evergreens.

EVERGREEN HEDGE PLANTS. American Arbor Vitae, Norway Spruce, Hemlock and Pines are used for hedges. See description of each under Evergreens.

CALIFORNIA PRIVET. This is the most glossy leaved and rapid growing of all the halfevergreen plants used for low hedges around private lawns and is the universal favorite at Newport and other fashionable seaside resorts. The plant has light green stems and white flowers in June. Transplants easily, grows in almost any soil and location, even where quite shaded, and can be trimmed to any desired form.

BARBERRY THUNBERGII. A comparatively new shrub of low growing habit, seldom over four feet, unrivalled for beauty. Foliage a bright green until autumn, when it changes to brilliant tints of crimson and yellow. The conspicuous crimson berries remain on throughout the winter giving a very pleasing effect.

JAPAN QUINCE, SPIREAS, LILACS, and other shrubs are used effectively as hedges.

Franklin Co., Mass., June 12, 1908.

Gentlemen :

The nursery stock you sent me was fine.

A. P. Noyes. 


\section{HERBACEOUS PERENNIAL PLANTS}

Below we mention a few of the best and most popular varieties of these useful plants which are exceedingly valuable on account of their hardiness, easy culture and showy appearance. These will live all winter in the open ground and bloom freely every year.

BLANKET FLOWER, (Gaillardia). A fine border plant with purple and yellow flowers two inches across.

BLEEDING HEART, (Dicentra). Brilliant rosy heart-shaped flowers hanging from a gracefully curved stem. Fine for borders:

BELLFLOWER or Balloon Flower. (Platycodon). Large bell shaped blue flowers which are borne profusely all summer on neat branched upright stalks.

CANDYTUFT. (Iberis Sempervirens). A desirable dwarf plant with evergreen foliage producing innumerable flat heads of pure white flowers during April and May.

CHRYSANTHEMUMS. Hardy. These give an immense profusion of blooms late in the season when other flowers have been destroyed by frost.

COLUMBINE. (Aquilegia Chrysantha). A fine garden plant. Bright golden yellow flowers with long thread-like spurs. Fragrant.

FOXGLOVE. (Digitalis). Handsome and showy with large tubular flowers thickly clustered on tall spikes They succeed everywhere and give a wealth of flowers during June and July.

GOLDEN GLOW. (Rudbeckia). A large showy plant six to eight feet high bearing profusely large yellow flowers on long graceful stems.

HELIANTHUS. Multiflorus. Hardy Sunflower. Large showy plants of easy culture with rich golden-yellow flowers of the size and form of Dahlias.

HIBISCUS. Crimson Eye. A variety of Marsh Mallow producing flowers of great beauty often six inches across, pure milk-white with a large spot of rich velvety crimson in center." Blooms freely all summer.

IRIS GERMAN. The flowers resemble mammoth orchids in their peculiar shape and delicate colors, shading, delicacy of structure, etc. In richness and purity of colors few flowers surpass them and they are more or less fragrant. They bloom profusely in spring and early summer and do well in ordinary garden soil, thriving year after year even if neglected.

IRIS JAPAN. (Kaempferi). There are no flowers, not even the finest Orchids, that exceed in beautiful and fantastic forms or in rich, pure and beautiful colors, the Japan Iris. Flowers are of immense size, often ten inches or more across, and are produced in a veritable cloud of bloom. The colors range from pure white through violet, lilac, rose, purple and blue and combinations of colors and markings almost impossible to describe. The season of blooming is June and July.

JAPAN PLUME GRASS. (Eulalia). Stalks four to six feet high with long narrow striped leaves and showy plumes which remain on all winter.

LARKSPUR, HARDY. (Delphinium). These produce long spikes of blue flowers from June until late in the fall.

PEARL. (Achille Ptarmica). Beautiful double clusters of pure white flowers blooming freely all summer. Excellent for cut flowers and cemetery planting.

PEONIAS. Beautiful, showy and easily cultivated. The newer varieties produce very large handsome regularly formed blooms resembling and rivalling the roses in brilliancy of color and perfection of bloom. We offer the best sorts varying from pure white, salmon and blush to lilac and deep rose.

PERENNIAL PEA. (Lathyrus Latifolius). A beautiful climbing plant with pale green foliage. Flowers, pea-like, deep rosy-red, produced in racemes in great abundance all summer. Superb for cutting.

PHLOX. The most widely known and popular of all garden plants commending itself to every one by its variety and beauty.

POPPY, ORIENTAL. These large flowered Poppies are among the most brilliant and showy of hardy plants. Flowers large, from four to six inches across, bright crimson with black center. May and June.

PLUME POPPY. (Bocconia Cordata). A tall stately plant with large terminal plumes of white flowers on stems six to eight feet high. July and August.

PYRETHUM ROSEUM. Fern-like foliage, flowers pink or red petals with vivid yellow centers resembling asters.

SPEEDWELL. (Veronica Longiflora). Flowers exquisitely beautiful of a rich deep blue color borne in dense, erect spikes a foot long, completely covering the plant. August and September.

SPIREA JAPONICA. (Astilbe). Handsome dark green foliage and showy spikes of pure white flowers. 


\section{ROSES \\ WINTER PROTECTION}

All roses in this climate will give better results if protected in winter. The best way is to cover the plant with dry leaves kept down with evergreen boughs, all of which should be removed early in spring. The Moss, Hybrid Perpetuals and the Climbing Roses are hardy. The Tea Roses are most beautiful, fragrant, constant bloomers, but are not hardy and will not live outside in our climate. The Hybrid Teas are also free bloomers and wil live outside with good protection.

\section{HYBRID PERPETUAL ROSES}

ALFRED COLOMB. Brilliant carmine crimson.

ABEL CARRIERE. Velvety crimson.

AMERICAN BEAUTY. Deep pink.

ANNE DE DIESBACH. Brilliant carmine.

BARON DE BONSTETTEN. Velvety maroon.

BARONESS ROTHCHILD. Clear pink, cupshaped flower, free bloomer.

CLIO. Flesh color, shaded with rosy pink.

DUKE OF EDINBURG. Rich, brilliant vermilion.

EARL OF DUFFERIN. Velvety crimson, shaded with maroon.

FISHER HOLMES. Deep glowing crimson.

FRAU KARL DRUSCHKI. Pure snow white, large, full flowers. The best white.

GENERAL JACQUEMINOT. Brilliant crimson.

GIANT OF BATTLES. Crimson, double.

GLOIRE LYONAISE. White, tinted yellow.

JEAN LIBAUD. Crimson maroon.
JOHN HOPPER. Bright rose.

JULES MARGOTTEN. Cherry red, free and reliable.

LOUIS VAN HOUTTE. Crimson, maroon, fragrant.

MABEL MORRISON. White, tinged with blush.

MADAM GABRIEL LUIZET. Silvery pink.

MARCH. OF LONDONDERRY. Silvery rose.

MARGARET DICKSON. White, flesh center.

MARSHALL P. WILDER. Cherry carmine.

MAGNA CHARTA. Clear, rosy red.

MRS. JOHN LAING. Soft pink.

PAUL NEYRON. Deep rose.

PIERRE NOTTING. Deep maroon.

PRINCE CAMILLE DE ROHAN. Deep velvety crimson.

ULRICH BRUNNER. Brilliant cherry red.

VICTOR VERDIER. Bright rose, carmine center.

\section{CLIMBING ROSES}

BALTIMORE BELLE. White.

QUEEN OF PRAIRIE. Bright rosy red.

YELLOW RAMBLER. Yellow in bud.

CRIMSON RAMBLER. Crimson.

WHITE RAMBLER. Small white flowers

DOROTHY PERKINS. Shell pink, scented.

\section{MOSS ROSES}

BLANCHE MOREAU. White.

SALET. Light rose.

CRIMSON GLOBE. Red.

\section{TEA AND HYBRID TEA ROSES}

CAPTAIN CHRISTY. Shell pink.

DUCHESS OF ALBANY. Deep pink, free blooming.

ETOILE DE FRANCE. Clear velvety, redcrimson, fragrant.

GRUSS AN TUPLITZ. Brightest scarletcrimson, very free.

K. A. VICTORIA. Creamy-white, very large.

KILLARNEY. Deep shell pink, blooms enormouts in size.
LIBERTY. Deep, bright crimson-scarlet.

LA FRANCE. Silvery pink.

WHITE LA FRANCE. White, tinted with flesh.

MAMAN COCHET. Carmine rose, shaded with yellow. Tea.

WHITE M. COCHET. Pure white, tinged with pink.

PERLE DES JARDINS. Deep golden-yellow.

\section{MISCELLANEOUS ROSES}

BABY RAMBLER. Deep crimson, perpetual and constant in bloom.

COQUETTE DES ALPS. White, tinged with carmine.

CLOTHILDE SOUPERT. White, rosy center, free bloomer.

HARRISON YELLOW. Light sulphur yellow.

HERMOSA (BOURBON). Bright pink, constant bloomer.

MADAM PLANTIER. Pure white, free bloomer.
MARECHAL NEIL. Deep golden-yellow.

PERSIAN YELLOW. Yellow.

RUGOSA RED AND WHITE. Large single flowers, followed by scarlet fruit.

SOLEIL D'OR. Yellow and reddish gold, hardy.

WHITE BABY RAMBLER. Creamy white, small flowers, constantly in bloom. 


\section{PRICE LIST \\ THE BARNES BROS. NURSERY Co.}

Incorporated.

\section{YALESVILLE, CONNECTICUT.}

\section{SPECIAL NOTICES TO CUSTOMERS}

ORDER EARLY. See reasons on inside cover page of our Catalogue.

OUR GUARANTEE. Customers will find it given in our Catalogue.

PACKING. All stock is packed and delivered on board cars, free of charge.

STATE INSPECTION. Our Nurseries have been thoroughly inspected, and found free from San Jose scale, and other injurious insects and diseases. Certificate of Entomologist accompanies shipments.

FUMIGATION. We fumigate all stock sent out with Hydrocyanic Acid gas as an effective insurance and safeguard.

TERMS. Cash in advance, or satisfactory references from parties unknown to us.

APPLICATION OF RATES. Purchasers may select 5, 50 and 500 of a kind at ten, hundred and thousand rates respectively.

ERRORS. We may sometimes make them in the rush of our busy packing season. Customers will confer a favor by notifying us promptly of any errors or discrepancies, so as to give us a chance to rectify as far as we can.

OUR PRICES may not be as low as the lowest, but prices should not always be the first consideration. The quality of the stock and the reputation of the firm should be considered as well as the price.

For further counsel, with hints on care and planting of stock, read our Catalogue through care fully, commencing at the beginning.

\section{FRUIT DEPARTMENT}

Height mentioned of Fruit Trees is approximate. In grading, the caliper usually governs instead of the height.

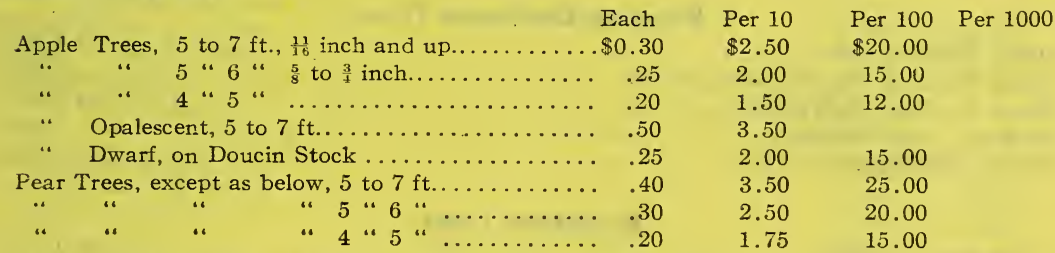

Bartlett, Clapp's Favorite and Seckel, 5c. each additional.

Kieffer, 5c. each less.

Peach Trees, 4 to $6 \mathrm{ft}$., $\frac{9}{16}$ inch and up......... .15

" " 4 " 4 " 5 " $\frac{1}{2}$ to $\frac{9}{16}$ inch............ .12

“ " " 3 " 4 " $\frac{7}{16}$ to $\frac{1}{2}$ inch............ .10

“ “ $\quad$ " medium, 3 to $4 \mathrm{ft}$., $\frac{3}{8}$ to $\frac{7}{16}$ inch......

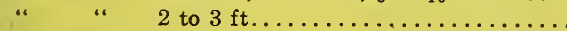

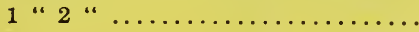

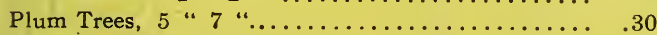

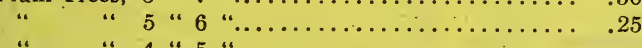

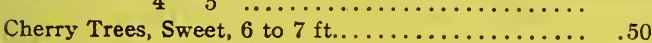

" 5 " 6 " 6 "

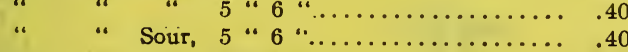

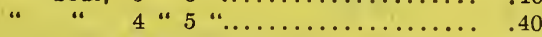

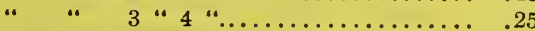

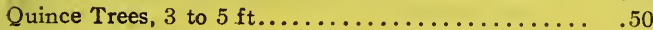

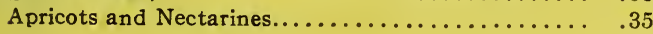

$\begin{array}{rrr}1.25 & 7.00 & \$ 65.00 \\ 1.00 & 6.00 & 55.00 \\ .90 & 5.00 & 45.00 \\ .80 & 4.50 & 40.00 \\ .75 & 3.50 & 30.00 \\ .60 & 3.00 & 20.00 \\ 2.50 & 20.00 & \\ 2.00 & 15.00 & \\ 1.50 & 12.00 & \\ 4.00 & 30.00 & \\ 3.50 & 25.00 & \\ 3.00 & 25.00 & \\ 2.50 & 18.00 & \\ 2.00 & 12.00 & \\ 3.50 & 30.00 & \\ 2.50 & & \\ & & \end{array}$




\section{ORNAMENTAL DEPARTMENT CDeciduous Trees $P$ I}

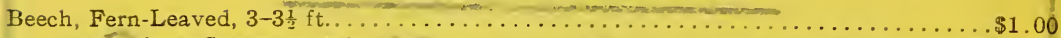

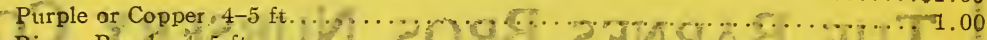

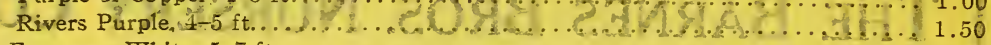

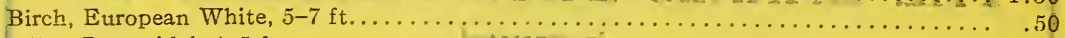

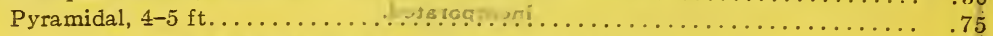

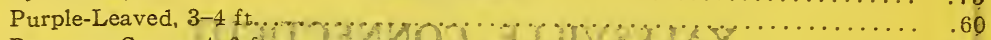

Paper, or Canoe, $-4-6$ ft....... 10 . .

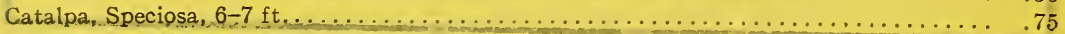

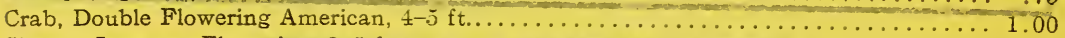

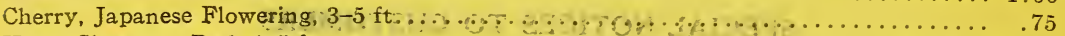

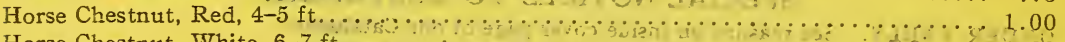

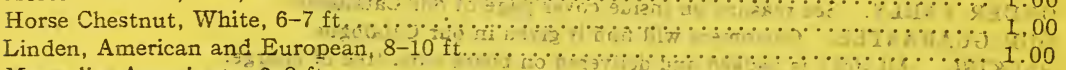

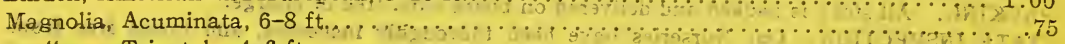

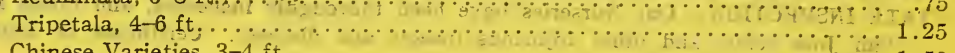

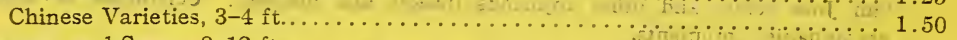

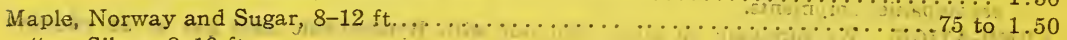

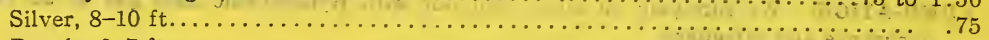

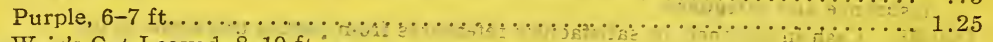

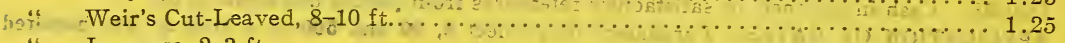

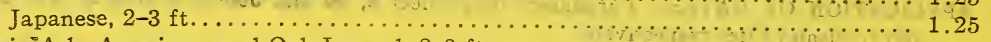

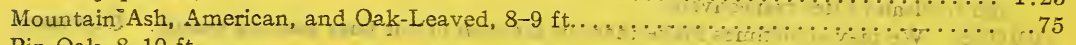

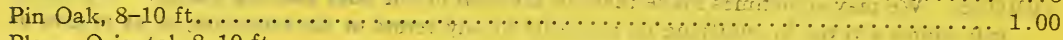

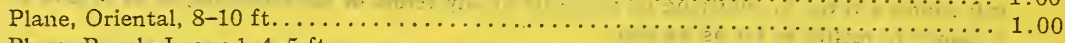

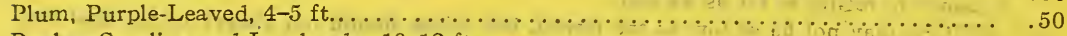

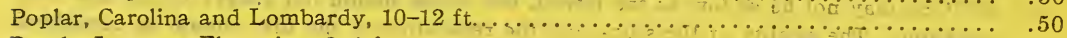

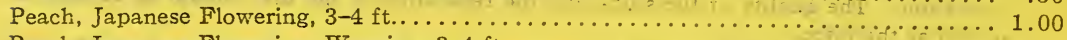

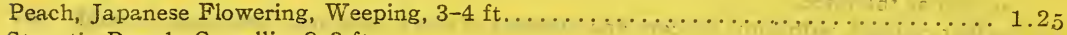

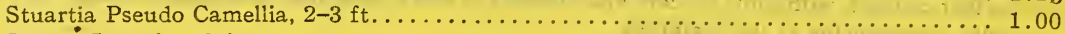

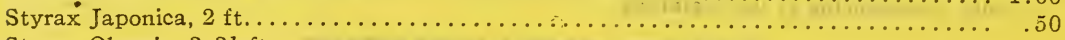

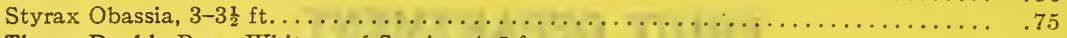

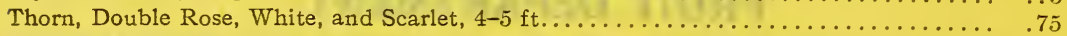

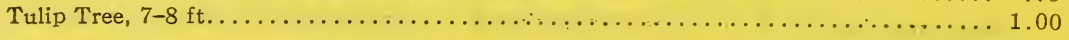

\section{Weeping Deciduous Trees}

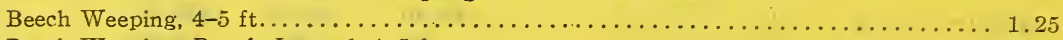

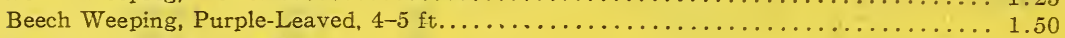

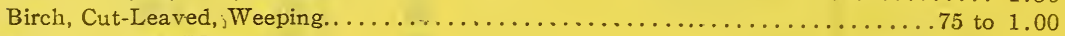

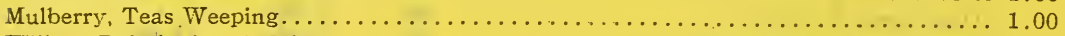

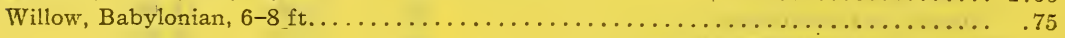

\section{Evergreen Trees}

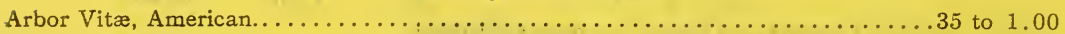

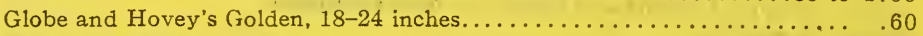

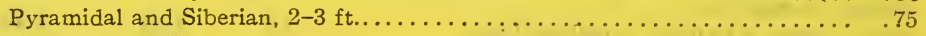

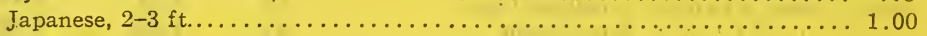

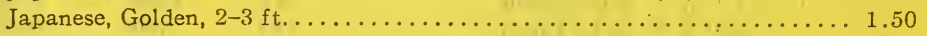

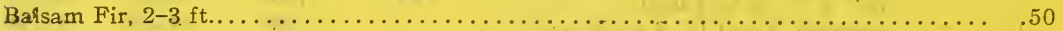

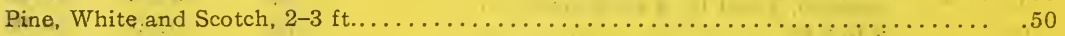

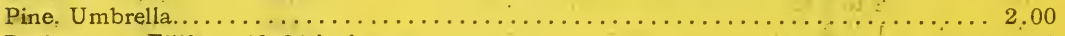

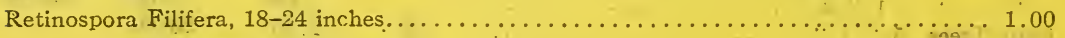

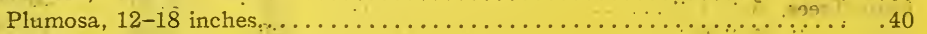

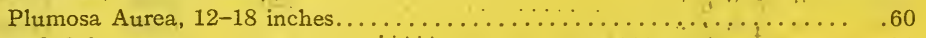

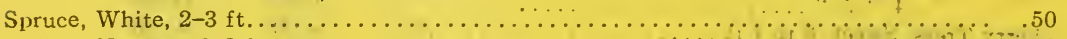

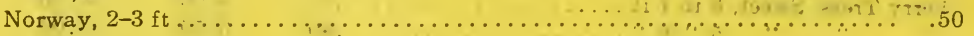

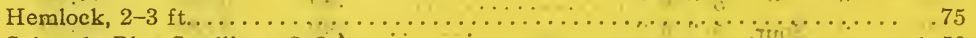

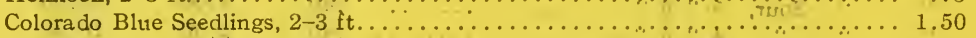

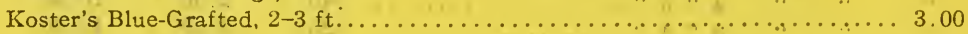

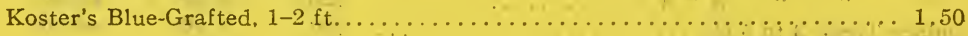




\section{Herbaceous Perennial Plants}

Varieties described in Catalogue 25c. each, $\$ 2.00$ per 10 except the following: 002

Golden Glow, Phlox and German Iris.................... each; $\$ 1.50$ per 10

Peonias, Herbaceous, according to variety and size of roots, $25 \mathrm{c}$, to $50 \mathrm{c}$, ea.; $\$ 2.00$ to $\$ 3.50$ per I0

\section{Deciduous Upright Shrubs}

For 25c. each; $\$ 2.00$ per ten. below:

We will furnish anything described under this head in our Catalogue except those priced

For 50c. each; $\$ 4.00$ per ten.

Red-Branched Dogwood, 3-4 ft.

Purple Fringe, $3-4 \mathrm{ft}$.

Red-Branched Dogwood, 3-4 ft.

White, Fringe, $2-3 \mathrm{ft}$.

Lilac, Chas. X., 2-3 ft.

Lilac, Marie Le Gray, 2-3 ft.

For $\$ 1.00$ each the following.

Rhododendrons, 18-24 inches, Tree Peonias, Hydrangea Hortensis.

Golden Syringa.

Aralia Spinosa, 4-6 ft.

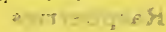

\section{Climbing and Trailing Shrubs} per 10 .

Everything described under this heading, except those priced below, $25 \mathrm{c}$. each; $\$ 2.00$

For 50c. each; $\$ 4.00$ per 10

Birthwort or Dutchman's Pipe.

Hydrangea Scandens.

\section{Rose Bushes}

Clematis Hybrids.

Wisterias.

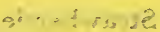

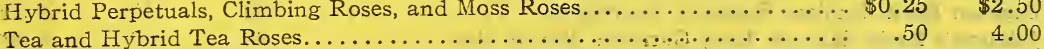

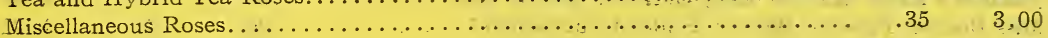

\section{Hedge Plants}

Per 100 Per 1000

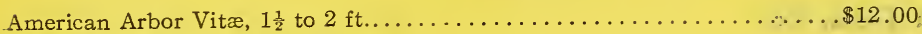

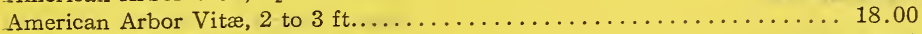

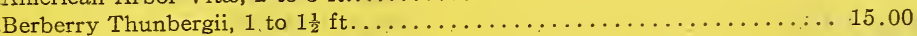

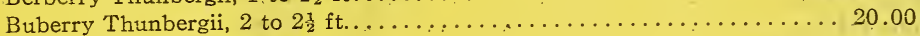

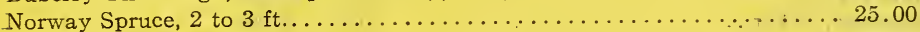

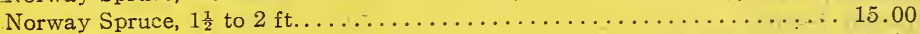

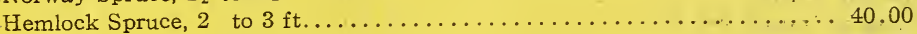

" " $1 \frac{1}{2}$ " 2 "

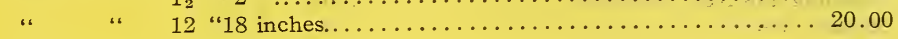

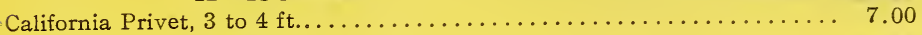

60.00

" " $\quad 2$ " 3 "

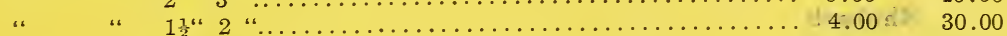

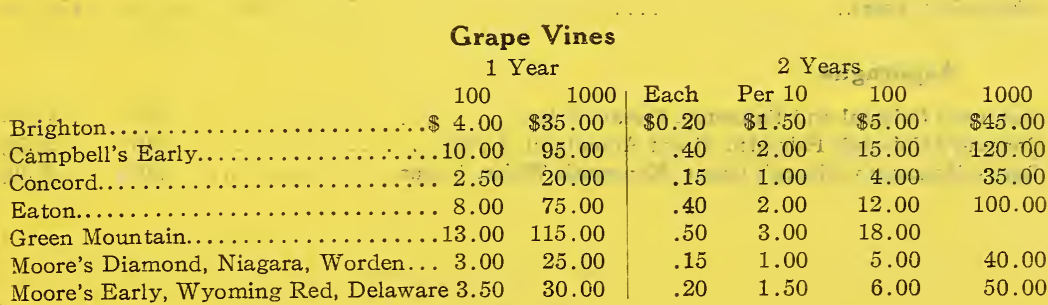

Moore's Early, Wyoming Red, Delaware 3.50 30.00

\section{Currants}

All varieties in Catalogue excepting Perfection, 2 years.........

All varieties in Catalogue excepting Perfection, 1 year...........

$1.00 \quad 4.00$

Perfection, 2 years. 


\section{Gooseberries}

Columbus, 2 years............................ $\$ 0.25$

Downing, Pearl, Smith's, Houghton, 2 years............... . 12

Downing, Pearl, Smith's, Houghton, 1 year.............. . 10

Josselyn and Industry, 2 years..................... .20

$\$ 2.00$

$1: 25$

1.00

1.50

$\$ 10.00$

7.00

12.00

\section{Blackberries}

Per 10

Eldorado................................. \$0.50

Ward, Mersereau, Rathbun..................... .50

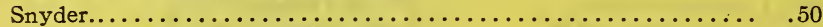

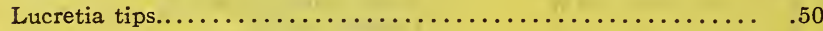

\section{Raspberries}

Herbert.............................. \$2.00

Kansas, Phœnix, Black Diamond, Conrath, Nemaha. Cumberland .50

Golden Queen,-Columbian, Plum Farmer, and Munger.......... . 50

Cuthbert................................ 50

15.00

2.00

2.00

1.50

12.00

\section{Strawberries}

Abington, Mead, Marshall, Gandy, Sharpless.............. . 25

Arnont, Bubach, Climax, Uncle Jim, Corsican............... . 20

Commonwealth, Glen Mary, Hummer, Nettie.............. . . 20

Oom Paul, Buster, Jessie, New York, Nick Ohmer............. . . 20

Beverly, Bismarck, Brandywine, Clyde, Crescent............ . .20

Dighton Rock, Dunlap, Excelsior, Haverland............. . . 20

Johnson's Early, Kansas, Lady Garrison, Minute Man........... . . 20

Miss Boston, Parsons' Beauty, Pride of Cumberland............ . . 20

Rough Rider, Sample, Saunders, Somerset Maid............. . . 20

Steven's Late Champion, Success, Warfield, Wm. Belt......... . .20

\section{Nut Trees, etc.}

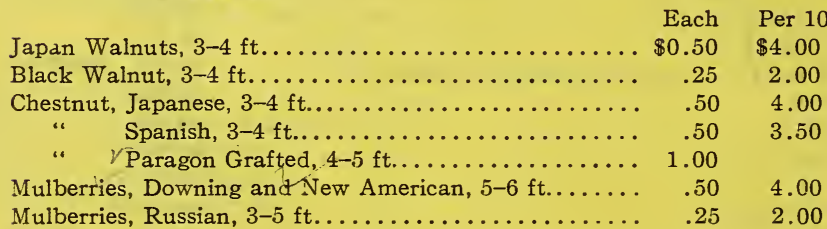

\section{Per 100 Per 100}

4.00

3.50

4.00

2.00

\section{Rhubarb}

Rhubarb, 2 years

\section{Asparagus}

Conover's Colossal and Palmetto, 2 year roots................... .60

Conover's Colossal, Palmetto, Giant Argenteuil, 1 year.............. $\quad .40$ 


\section{ENEMIES OF FRUIT TREES AND PLANTS}

Only a few years ago little or nothing was known about fungous diseases, and almost nothing about the insects that trouble the fruit-grower. But we know now the life history of all the common insects, as well as fungous diseases, and know how to combat them at each stage of their life. It is only necessary to follow directions, and be prompt and thorough, to insure success. A man will spend weeks cultivating his corn field, that will barely yield a crop to cover the labor, and begrudge a week's time to his fruit that will yield him returns running into hundreds of dollars' profits per acre.

\section{INSECTS}

There are some insects that escape our attention entirely unless we look closely. Among these are the gnats, mites, scale lice, and the ordinary plant-lice. These are all insects that live by sucking the sap of the plant for food, and have to be combated with some mixture that dries on them, stopping up their breathing pores, which are arranged along their sides, or else by their caustic action eats away their tissues and destroys them. They have a great many natural enemies. Among them are the Ichenumon Fly - a fly looking much like a tiny wasp-and the Lady Bug. The insects that eat the leaves for food, such as the Potato Bug, the Apple Tree Tent Caterpillar, etc., are killed by poisoning their food, and some form of arsenic has been found best for this purpose.

\section{FORMULAS FOR SPRAYING}

PARIS GREEN. $1 \mathrm{lb}$. Paris Green, 3 lbs. lime, 100 gallons water. Spray upon foliage to kill elm leaf beetle and all biting insects. Commonly used with Bordeaux Mixture.

KEROSENE EMULSION. 2 gals. kerosene, 1/2 1b. common soap, 1 gal. water. Dissolve the soap in hot water, add kerosene, and churn all together until a white creamy mass is formed, which thickens on cooling. Dilute nine times before using. This is to kill the sucking insects.

LIME SULPHUR SPRAYING MIXTURE. $14 \mathrm{lbs}$. lime, $14 \mathrm{lbs}$. flowers of sulphur, 40 gals. water. Put about one-third of the water in a receptacle, then the sulphur and lastly the lime, and stir constantly until the lime is slaked, then boil for an hour, or until the mixture becomes a reddish amber color, which indicates the sulphur has been dissolved. Add balance of water, and it is ready for use. Only best quality of fresh lime should be used. This mixture should be applied while fresh, and only on dormant trees, to kill San Jose scale insect.

BORDEAUX MIXTURE, 4 lbs. copper sulphate, 4 lbs. fresh lime, 40 to 50 gals. water. Dissolve the copper sulphate in hot water, or from a coarse bag suspended in cold water; slake the lime separately. Dilute the former to about 20 gals., into which pour the lime diluted to about 10 gals., stirring the mixture; dilute further to form the 40 or 50 gallons. Stock solutions of the copper sulphate or lime, rate $1 \mathrm{lb}$. to 1 gal. water, can be kept indefinitely. Bordeaux Mixture is for fungous diseases, and by adding Paris Green to it, it can be made a remedy for both fungous and insects. 3 ounces of Paris Green to the barrel is enough. The Bordeaux mixture, when used on such plants and trees as the peach and Japanese plum, should only be used about half the above strength, as the foliage is injured by the stronger mixture.

We aim to keep on hand an up-to-date line of SPRAYING IMPLEMENTS, including Pumps, Hose, Nozzles and other equipment for spraying. Catalogue of Spraying accessories sent on request. 


\title{
THE BARNES BROS. NURSERY CO.
}

INCORPORATED

\author{
: NURSERYMEN:
YALESVILLE $:::$ :
CONNECTICUT

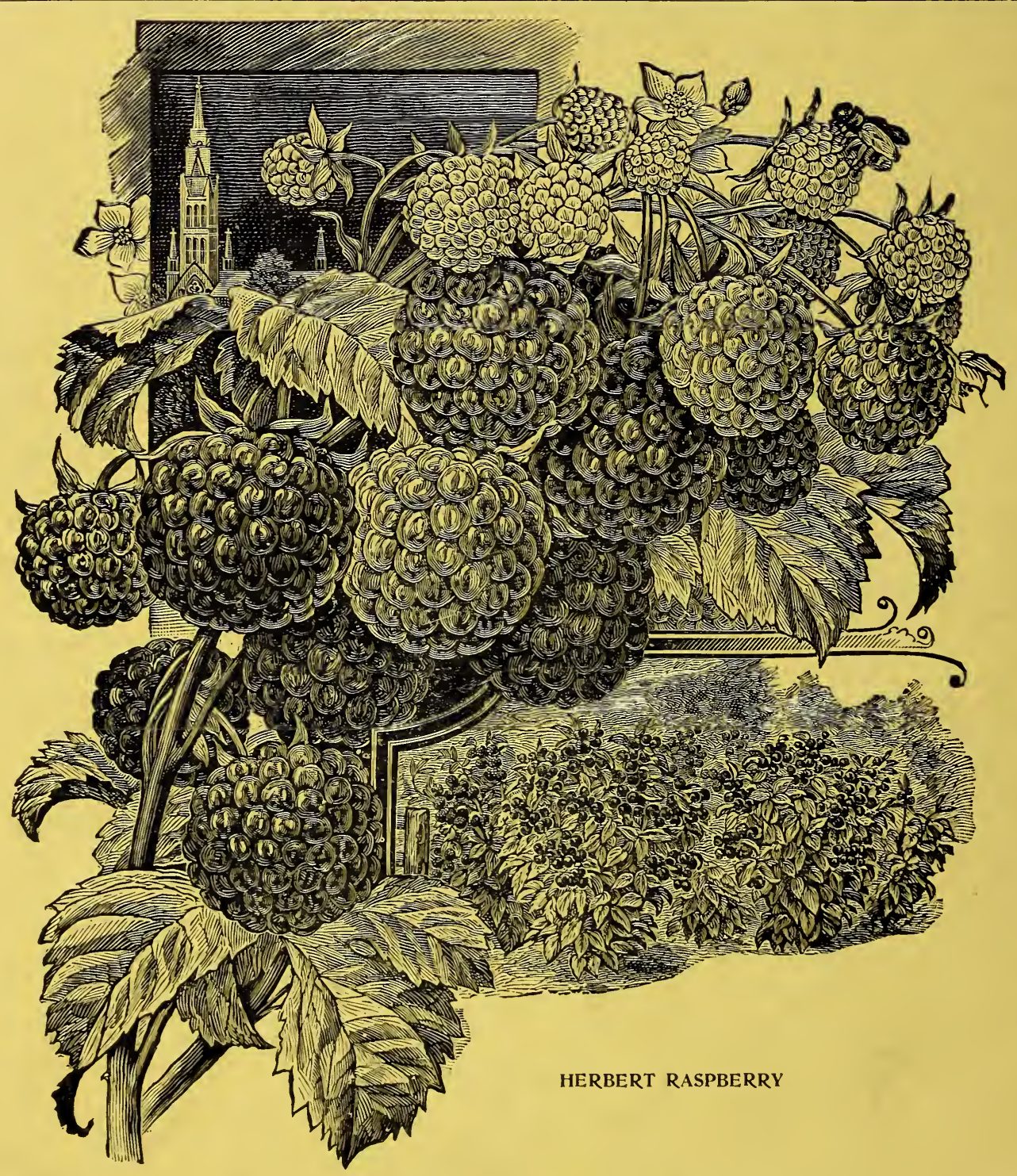

AS CHOICE A COLLECTION OF

: FRUIT TREES: 